\title{
Nano-Antibacterials Using Medicinal Plant Components: An Overview
}

\author{
Sourav Ghosh, Susmita Nandi and Tarakdas Basu* \\ Department of Biochemistry and Biophysics, University of Kalyani, Kalyani, India
}

Gradual emergence of new bacterial strains, resistant to one or more antibiotics, necessitates development of new antibacterials to prevent us from newly evolved disease-causing, drug-resistant, pathogenic bacteria. Different inorganic and organic compounds have been synthesized as antibacterials, but with the problem of toxicity. Other alternatives of using green products, i.e., the medicinal plant extracts with biocompatible and potent antibacterial characteristics, also had limitation because of their low aqueous solubility and therefore less bioavailability. Use of nanotechnological strategy appears to be a savior, where phytochemicals are nanonized through encapsulation or entrapment within inorganic or organic hydrophilic capping agents.

OPEN ACCESS

Edited by: Gerson Nakazato,

State University of Londrina, Brazil

Reviewed by:

Ren-You Gan

Institute of Urban Agriculture, Chinese Academy of Agricultural Sciences

(CAAS), China

Doumit Camilios Neto,

State University of Londrina, Brazi Nilton Syogo Arakawa, State University of Londrina, Brazil

*Correspondence:

Tarakdas Basu tarakdb@yahoo.com

Specialty section:

This article was submitted to Antimicrobials, Resistance and Chemotherapy,

a section of the journal

Frontiers in Microbiology

Received: 01 September 2021 Accepted: 13 December 2021 Published: 22 February 2022

Citation:

Ghosh S, Nandi S and Basu T (2022) Nano-Antibacterials Using Medicinal Plant Components: An

Overview.

Front. Microbiol. 12:768739. doi: 10.3389/fmicb.2021.768739
Nanonization of such products not only makes them water soluble but also helps to attain high surface to volume ratio and therefore high reaction area of the nanonized products with better therapeutic potential, over that of the equivalent amount of raw bulk products. Medicinal plant extracts, whose prime components are flavonoids, alkaloids, terpenoids, polyphenolic compounds, and essential oils, are in one hand nanonized (capped and stabilized) by polymers, lipids, or clay materials for developing nanodrugs; on the other hand, high antioxidant activity of those plant extracts is also used to reduce various metal salts to produce metallic nanoparticles. In this review, five medicinal plants, viz., tulsi (Ocimum sanctum), turmeric (Curcuma longa), aloe vera (Aloe vera), oregano (Oregano vulgare), and eucalyptus (Eucalyptus globulus), with promising antibacterial potential and the nanoformulations associated with the plants' crude extracts and their respective major components (eugenol, curcumin, anthraquinone, carvacrol, eucalyptus oil) have been discussed with respect to their antibacterial potency.

Keywords: medicinal plants, major components, nanonization, antibacterials, mechanism of action

\section{INTRODUCTION}

Bacteria are ubiquitous in nature and play an important role to keep up the homeostasis in the environment in which we live (Doron and Gorbach, 2006). Bacteria have both beneficial and harmful effects in public health. So far as their helpful roles are concerned, they provide vital ecosystem services. Bacterial species like Bacillus subtilis, Pseudomonas fluorescens, and others decompose dead organisms to release inorganic elements to maintain the balance in continuity of carbon and nitrogen cycles and thus clean the environment (Sivasakthi et al., 2014). Bacteria are very much useful for civilization in the aspect of multiple purposes such as for production of ethanol, enzymes, antibiotics, and biogas; for fermenting cheese and yogurt; for cleaning of oil spills and toxic wastes; and also in many more fields (Raaijmakers et al., 2002; Ma et al., 2009; Das and Chandran, 2011; Youngsukkasem et al., 2012; Singh and Singh, 2014; Li et al., 2020). The human gut is colonized by $10^{14}$ microbes, out of which bacteria consist of a major part as 
commensal ones (Zhang et al., 2015). Gut bacteria provide essential nutrients, synthesize vitamin $\mathrm{K}$, help in digestion of food stuff dietary fibers-polyphenols, and also encourage angiogenesis and enteric nerve functions (Tsuji et al., 2008; Hill and Artis, 2010). Breakdown of gut environmental homeostasis leads to dysbiosis of bacteria, which may cause different types of illness like allergy, inflammatory bowel disease (IBD), obesity, diabetes, and even cancer (Ticlla et al., 2021).

On the other hand, bacterial species like Mycobacterium tuberculosis, Vibrio cholerae, and Salmonella typhimurium having a deleterious role of causing diseases are called pathogenic bacteria. Development of antibacterials is necessary to combat the pathogenicity of such disease-causing bacteria. The disease tuberculosis, caused by Mycobacterium tuberculosis, spreads through contaminated air and approximately 27,000 people are affected by tuberculosis with about 4,000 deaths per day from this disease (Yamano, 2019). WHO listed two bacterial pathogens Pseudomonas aeruginosa and Acinetobacter baumannii as a public health threat for developing nosocomial disorders like pneumonia, sepsis, bacteremia, urinary tract infections, and various complications in lungs (Mwangi et al., 2019). An important life-threatening bacterial disease is cholera, which is caused by Vibrio cholerae and is transmitted by contaminated food and water. As per WHO report (February 5, 2021), about 1.3-1.4 million cases of cholera infection occur globally each year and the number of deaths ranges from about 21,000143,000 from country to country. An important water-borne, Salmonella typhi-mediated fatal disease is typhoid fever, by which about 21 million illnesses and 2,16,500 deaths occurred globally in 2000, affecting all age groups (Bhan et al., 2005). A fulminant zoonotic complication "plague" is caused by the bacteria Yersinia pestis and Yersinia pseudotuberculosis, and in the history of earth, plague had been appeared multiple times as epidemic (Prentice and Rahalison, 2007). Another major health problem in most developing countries is dysentery that is caused by different enteropathogenic bacteria such as Shigella flexneri and Shigella dysenteriae. Dysentery causes more than 1 million deaths globally each year and children specifically under 5 years are more susceptible for the infection (Mukherjee et al., 2019). Besides these, some clinically relevant infections are meningitidis (a disease of brain characterized by fever, headache, vomiting, inability to lower chin to chest, non-specific maculopapular rash, joint pain, sign of vasculitis, and also appearance of conjunctivitis, panophthalmitis, and pneumonia caused by Neisseria meningitides; Stephens et al., 2007) and sexually transmitted diseases like syphilis and gonorrhea caused by Treponema pallidum and Neisseria gonorrhoeae, respectively (Workowski et al., 2015). Thus, bacterial infections have a great impact on public health, which is a fundamentally important issue for maintaining the stability and wellbeing of a nation or region.

An important phenomenon of bacterial infection is biofilm formation. Bacteria alternate between two forms-free-living planktonic and surface-attached biofilm-depending on the environmental conditions. Biofilm is a bacterial assemblage enclosed in self-produced extracellular polymeric substance (EPS), which is made up of extracellular DNA, polysaccharides, and proteins. EPS prevents the direct exposure of biofilmresiding cells to the different types of antibacterials. Biofilm causes more than $80 \%$ of chronic infections like pneumonia in cystic fibrosis patients, chronic wounds, chronic otitis media, and organ implant and catheter-associated infections (Bjarnsholt, 2013). Such infections affect millions of people globally with consequent death of millions of people each year (Bjarnsholt, 2013).

To prevent bacterial infections, there are various approaches. The conventional antibacterial approach is the use of antibiotics, but most of the clinically important bacterial infections are gradually going to be antibiotic resistant. Biofilm infections are the hallmark of antibiotic resistance (Levy and Marshall, 2004). Antibiotics work in a specific way so that a particular cellular process (synthesis of cell wall, protein, DNA, and RNA) is disturbed and therefore bacteria become easily antibiotic resistant by acquiring mobile genetic elements such as bacteriophages, plasmids, naked DNA, transposons, or through chromosomal mutation also (Milkman, 1990; Schneiders et al., 2003). The problem of antibiotic resistance generation in bacteria led to the exploration of the synthesis of different inorganic (particularly metals and metal oxides like $\mathrm{Au}, \mathrm{Ag}, \mathrm{Cu}, \mathrm{Zn}, \mathrm{CuO}, \mathrm{ZnO}, \mathrm{MgO}$, and $\mathrm{TiO}_{2}$; Saidin et al., 2021) and organic (chlorohexidine, triclosan, polyaniline, polyethylenimine) molecules as antibacterials (Saidin et al., 2021). Such molecules were found to combat infection of a broad spectrum of bacteria like Escherichia coli, Staphylococcus aureus, Klebsiella pneumoniae, Salmonella typhimurium, and many others. They attack the bacteria through various routes, viz., membrane disruption, DNA damage, protein synthesis inhibition, and free radical generation (Soenen et al., 2011); however, the major problem of their use is cytotoxicity, which is generated by excessive ROS (reactive oxygen species) production, changes in cell morphology with cytoskeleton defects, introduction of genotoxicity, and so on (Soenen et al., 2011). To annihilate the problem of cytotoxicity, green products, especially the medicinal plant components, represent a better biocompatible platform with significant antibacterial potential (Sdrolia and Zarotiadis, 2018). However, most of such plants' ingredients are poorly soluble in aqueous media, i.e., poorly bioavailable and are not highly stable too. To make them bioavailable and stable, the use of nanotechnological strategy is increasing, where hydrophobic active components of plants are nanonized through encapsulation or entrapment within inorganic or organic nanocarrier molecules, as shown in the representative Figure 1. Such nanoformulations of medicinal plant products are found to have enormous therapeutic potential against bacterial infection. Nanomedicines developed by this strategy are found to have the property of sustained release of active drug component from nanocarrier molecule and thereby retaining the drug efficacy for a longer period (Sarmukaddam et al., 2010). In addition, medicinal plant extracts are also used as nanocarrier/nanostabilizer to reduce metal salts/oxides of $\mathrm{Ag}$, $\mathrm{Au}, \mathrm{Cu}$, and $\mathrm{Zn}$ to metallic nanoparticles (NPs) by their high antioxidant activity, producing green synthesized metallic NPs as potential antibacterials (Dubey et al., 2010; Zamare et al., 2016; Mali et al., 2020; Jayachandran et al., 2021). In this article, 


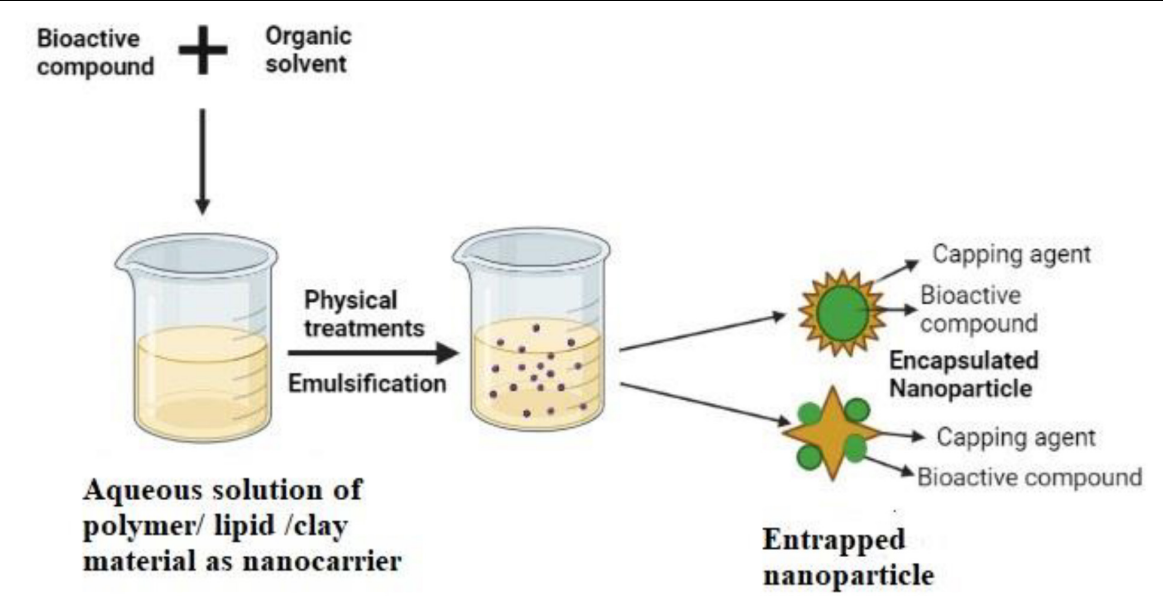

FIGURE 1 | Schematic representation of active compound loaded nanoparticle.

antibacterial action of five important medicinal plant extracts, viz. tulsi (Ocimum sanctum), turmeric (Curcuma longa), aloe vera (Aloe vera), oregano (Oregano vulgare), and eucalyptus (Eucalyptus globulus), and their respective major components eugenol, curcumin, anthraquinone, carvacrol, and eucalyptus oil in nano-forms has been reviewed.

\section{TULSI (Ocimum sanctum)}

This flowering plant of the mint family (Lamiaceae) is very much common in the Indian subcontinent and grows throughout Southeast Asia. The literal meaning of the term "Tulsi" means incomparable one and this plant is also considered as "queen of herb" because of its diverse healing and health-improving properties to the human body. This medicinal plant is widely used centuries after centuries in traditional medicinal practice. Ancient Indian medical practitioners and scientists described "Tulsi" as an adaptogen, which balances different processes of the body, helps to adapt to the stresses, and boosts energy. Tulsi is regarded as "elixir of life" because of its excellent and versatile therapeutic potentials. Different parts of the plant (leaves, stem, roots, seeds, flowers) are used in traditional medicine sector, but most of the medicinal formulations are based on leaf extract because of its highest adaptogenic and antioxidant activities. Tulsi extract has been recommended to treat malaria, diarrhea, dysentery, skin disease, eye disease, and so on (Pattanayak et al., 2010). The extract has also been found to possess anticancer, hepatoprotective, antiemetic, antispasmodic, analgesic, antidiabetic, and anti-arthritis actions (Prakash and Gupta, 2005). It also reduces the risk of heart attack and lowers the cholesterol level (Bhargava and Singh, 1981; Gupta et al., 2002). The herbal formulation of tulsi is used for asthma, short breath, and also in respiratory ailments like bronchitis and tuberculosis (Das and Vasudevan, 2006).

So far as our knowledge goes regarding nanoformulations using medicinal plant extracts, there is hopefully no report of nanonization of whole extracts of any plant part through encapsulation or entrapment within any nanocarrier molecule, but there are reports about the use of plant extract as stabilizing agent to produce metallic and metal oxide NPs. Tulsi extract has been used to produce and stabilize silver nanoparticles (AgNPs) from the precursor silver nitrate molecules. During such green synthesis (phytoreduction) of silver NP, tulsi leaf extract converts silver ion into elemental silver by reduction of silver nitrate and produces monodispersed, spherical AgNPs of size about $20 \mathrm{~nm}$. Such AgNP preparation is found to have more antibacterial activity on Escherichia coli and Staphylococcus aureus, compared with the individual precursors silver nitrate and leaf extract. This becomes evident from the size of the zones of inhibition measured to be about $10.5,0$, and $8 \mathrm{~mm}$, respectively, for equivalent concentrations of AgNPs, silver nitrate, and leaf extract (Ramteke et al., 2013). This result implies that both the nanoformulation and the leaf extract have antibacterial activity and the activity of the nanoformulation is about $25 \%$ more than that of the leaf extract, whereas silver nitrate itself has no antibacterial activity. Paper towels coated with such tulsi extract-stabilized AgNPs have antibacterial activity against Escherichia coli, Staphylococcus aureus, and Klebsiella pneumoniae (Jacob et al., 2019). Such AgNP-coated cotton and leather surfaces inhibit growth of Bacillus linens, Pseudomonas acnes, Bacillus cereus, and Staphylococcus epidermidis (Jacob et al., 2019). AgNPs continuously release $\mathrm{Ag}^{+}$ions, which have strong affinity to cell wall and sulfur proteins. The adhered ions enhance permeability of cytoplasmic membrane and thus lead to bacterial cell wall disruption (Khorrami et al., 2018). After having entered into the cells, silver ion deactivates respiratory enzymes and produces ROS by inhibition of ATP generation (Ramkumar et al., 2017). ROS causes membrane disruption leading to problems in DNA replication and cell division (Yin et al., 2020), as bacterial DNA is believed to remain attached with cell membrane for a considerable time of their life cycle. Silver ion is also reported to inhibit protein synthesis by disintegrating ribosomes (Durán et al., 2016).

The phytochemical composition differs in various parts of the plant. The most commonly used leaf extract as medicines 


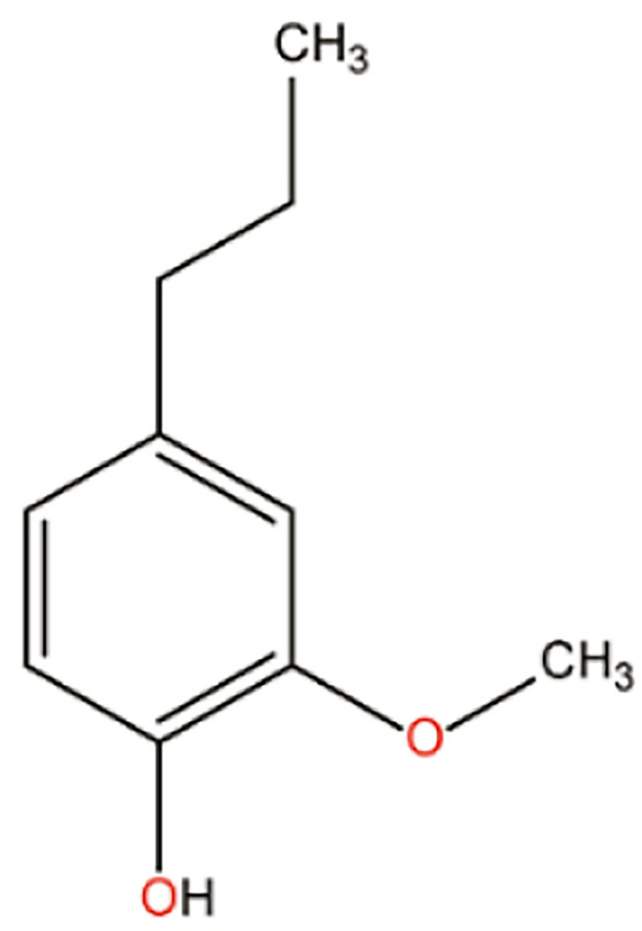

FIGURE 2 | Chemical structure of eugenol.

contains several volatile oils such as eugenol, euginal, urosolic acid, carvacrol, limatrol, caryophyllene, and estragol. Several groups report that the therapeutic potential of tulsi is mainly for the major bioactive component eugenol (approximately 67\%) (Prakash and Gupta, 2005; Pattanayak et al., 2010; Singh et al., 2010). Eugenol is a compound of the phenylpropanoid class, being one of the main components of the essential oil of Ocimum sanctum; its chemical structure is shown in Figure 2.

Eugenol is mainly used in food and cosmetics as flavoring agent. It is also known for its excellent antibacterial potential against a wide range of gram-negative (Escherichia coli, Pseudomonas aeruginosa, Pseudomonas fluorescens, Helicobacter pylori, Salmonella typhimurium) and grampositive (Staphylococcus aureus, Staphylococcus mutans) bacteria (Marchese et al., 2017). Eugenol, being hydrophobic and so lipophilic in character, preferentially partitions itself from aqueous phase into bacterial cell membrane. Eugenol affinity to cell membrane causes an increase in membrane permeability and therefore disturbance in ion transport processes; eugenolmediated inhibition of $\mathrm{H}^{+}$ion transport through cell membrane prevents ATP synthesis and respiratory processes; increased permeability causes cell membrane to lose its integrity and thereby to promote release of intracellular proteins into cell exterior (Gill and Holley, 2004; Kasi et al., 2010). Eugenol, by altering the ion transport through cell membrane, is also capable of generating intracellular ROS, which causes biomacromolecular damages such as DNA degradation, protein oxidation, lipid peroxidation, and ultimately cell death (Marchese et al., 2017). The hydroxyl group of eugenol inhibits the action of protease, histidine carboxylase, and amylase by binding to them in Enterobacter aerogenes (Marchese et al., 2017). Eugenol is also reported to reduce significantly in Staphylococcus aureus the production of (1) enterotoxins (A and B); (2) toxin 1, the key exotoxin that triggers toxic shock syndrome by inducing TNF-release; and (3) alpha-hemolysin that causes hemolysis of RBC in Staphylococcus aureus-infected population (Rafiee et al., 2019). These non-specific actions of eugenol led many laboratories to formulate nano-eugenol, to increase the aqueous solubility and antibacterial potential of eugenol. Different methods of nanonization of eugenol and the antibacterial potencies of the synthesized nano-eugenol have been discussed in the sections that follow.

\section{NANO-FORMULATIONS WITH EUGENOL}

Grafting of eugenol molecules on chitosan nanoparticle has been produced through gelation method by Schiff base reaction. According to this method, chitosan-NP is first synthesized by dropwise adding sodium triphosphate to acetic acid solution of chitosan. Eugenol grafting is then performed by adding eugenol into chitosan-NP in presence of methanol under stirring condition (Chen et al., 2009). Such nanoformulation of eugenol is found to have about twofold high antioxidant as well as antibacterial efficacies against Staphylococcus aureus and Escherichia. coli, compared with raw eugenol in bulk form (Chen et al., 2009). Nanonization of eugenol by entrapping within the synthetic polymer PLGA (poly lactic-co-glycolic acid) has been achieved by solvent evaporation technique, where organic and aqueous phases are emulsified homogeneously through sonication, to remove the organic solvent and finally to produce the polymer-capped NP. Here, organic phase contains PLGA, eugenol, and dichloromethane whereas aqueous phase contains surfactant poly vinyl-alcohol (PVA) as the stabilizing agent and these eugenol-entrapped PLGA-NP has 10 times more inhibitory role than free eugenol on the growth of Salmonella typhimurium, Listeria monocytogenes, and Listeria innocua (Gomes et al., 2011). Solvent evaporation method has also been used to synthesize eugenol-loaded zein (a protein in maize) NP; zein-NP represents a biocompatible carrier for bioactive ingredients. Here, organic phase contains zein and eugenol while aqueous phase contains the surfactant pluronic F 68. Zein nanoparticle-based highly monodispersed eugenol nanoformulation of size $150 \mathrm{~nm}$ and zeta potential $30 \mathrm{mV}$ has high encapsulation efficiency (more than 90\%) and also exerts a promising bactericidal activity against fish pathogenic bacteria Aeromonas hydrophila, Edwardsiella tarda, and Streptococcus iniae with less toxicity in fishes (Luis et al., 2020). Eugenol-entrapped ethosome nanoparticle (ELGNP) has been synthesized by ethosome preparation, using eugenol, ethanol, and lipid lecithin as precursors. During preparation of ELG-NP, ethanol, eugenol, and Tween 80 (as stabilizing agent) are first mixed; lecithin is then added dropwise under stirring condition to obtain homogenous ELG-NPs. Such nanoformulation has six times more antibacterial potency than free eugenol against fruit anthracnose (dark lesions on fruits)causing pathogen Collectotrichum sp. (Jin et al., 2019). The 
entrapment efficiency, particle size, and antibacterial activity of ELG-NPs depend on the percentage of reaction ingredients; $0.5 \%$ eugenol, $2 \%$ lecithin, and $30 \%$ ethanol are the optimum concentrations to produce the most effective ELG-NPs of size $44 \mathrm{~nm}$, with $82 \%$ entrapment efficiency and more than $93 \%$ antibacterial potency (Rodenak-Kladniew et al., 2019). There is a report on the synthesis of a hybrid eugenol/ofloxacin (quinolone antibiotics used to treat pneumonia, cellulitis, and urinary tract infections)-loaded solid-lipid nanoparticle by emulsification technique. In this method, lipid phase containing lipid, eugenol, and ofloxacin is injected into the aqueous phase of surfactant pluronic F 68 under stirring condition to emulsify lipid and aqueous phases. The emulsified mixture is then suddenly freeze dried to solidify the lipid and to finally obtain powder form of the nanoformulation, which is preserved at $5^{\circ} \mathrm{C}$. This hybrid solidlipid nanoparticle exhibits 6-16-fold better therapeutic potential than free eugenol and ofloxacin against Staphylococcus aureus and Pseudomonas aeruginosa (Rodenak-Kladniew et al., 2019).

Eugenol has the ability to break bacterial communication, termed as "quorum sensing," and thus inhibits bacterial biofilm formation. Quorum sensing is a kind of regulation of gene expression in response to alteration of cell population density. The sensing system comprises the sensing molecules, called "auto-inducers," auto-inducers producing proteins (LuxI), and the sensing receptor (LuxR). Gram-negative bacteria produce acyl-homoserine lactone (AHL) as the auto-inducer molecules, while Gram-positive bacteria use oligo-peptides as the same. When cell population reaches a particular threshold density, they produce auto-inducers, which are transported to the exterior of the cells by passive diffusion (for Gram-negative bacteria) or by ATP-binding cassette-transporter system (for Gram-positive bacteria). When extracellular concentration of auto-inducer molecules reaches a critical value, they bind to their sensing receptors of cells to activate the downstream signaling events to produce virulent factors and thus disease progression (Pena et al., 2019). In case of biofilm infection, eugenol inhibits the synthesis and or competes with autoinducer molecule to bind with quorum sensing receptor and consequently inhibiting the downstream signaling events. Beside this, eugenol also modulates the conformation of LuxR so that auto-inducer cannot bind properly to the receptor molecule. Inhibition of quorum sensing leads to reduce the production of virulence factors such as pyocyanin, elastase, rhamnolipid, and extracellular polysaccharide in Pseudomonas aeruginosa (Rathinam et al., 2017). Pseudomonas aeruginosa contains three well-known quorum sensing systems: LasI/LasR, RhlI/RhlR, and PQS (Pseudomonas quinolone signal)/PqsR (Pseudomonas quinolone signal receptor). Nanoemulsion of eugenol and eugenol alone reduce the expression of quorum sensing-related genes in Pseudomonas aeruginosa and, therefore, production of virulent factors is also reduced. At a concentration of $0.2 \mathrm{mg} / \mathrm{ml}$, nanoformulation and free eugenol display expression level to be respectively, 52 and $65 \%$ for LasI, 45 and $61 \%$ for RhlI, and 51 and $65 \%$ for RhlA, compared with untreated control $P$. aeruginosa cells. Therefore, nanoemulsion of eugenol exhibits inhibitive effects approximately $13-16 \%$ more than free eugenol on quorum sensing-related proteins (Lou et al., 2019). LasA and RhlA encode enzymes such as LasA protease, elastase, and rhamnolipid synthase, which are transcriptionally regulated by quorum sensing and are actively involved in exhibiting virulence in chronic biofilm infection (Adonizio et al., 2008). The oilin-water nanoemulsion is prepared by mixing pure eugenol, medium-chain triglycerides, surfactant Tween 80 , and phosphate buffered saline. Oil phase contains eugenol and medium-chain triglyceride, in which surfactant Tween 80 is injected under sonication to obtain a homogenous mixture and then the mixture is slowly titrated with $88 \%$ phosphate buffered saline for $30 \mathrm{~min}$ to develop well-dispersed nanoemulsion of eugenol, which shows an inhibitory effect on quorum sensing-associated virulence factors to inhibit biofilm formation by Pseudomonas aeruginosa (Lou et al., 2019).

\section{TURMERIC (Curcuma longa)}

The plant generally grows in warm climate, especially in India and many other parts in Asia (Lakshmi et al., 2011). Actually, the rhizome of the plant is used in spices and medicine. In folk and traditional medicine, turmeric had been used for its versatile therapeutic profile over the centuries in different parts of the world. It is believed from practical experience that turmeric strengthens the human body with overall energy, relieves the body from inherently produced gas, dispels worms, improves digestion, regulates menstruation, dissolves gallstones, and relieves arthritis. From ancient times to the modern era, turmeric is very much popular to treat sprains and swelling. Of the plant-based medicines, turmeric has a multitude of pharmacological properties and is used to combat various microbial diseases like runny nose, cough, sinusitis, and respiratory complications (asthma, bronchial hyperactivity), together with other diseases like liver disorders, anorexia, rheumatism, diabetes, and diabetic wounds, and even cancer also (Luthra et al., 2001). Various multinational companies are using turmeric to prepare face creams because of its significant antibacterial activities (Rafiee et al., 2019).

The excellent pharmacological activities of turmeric have led many laboratories to use it as stabilizing/encapsulating agent for synthesis of metal NPs and to investigate whether the individual antibacterial potency of metal NP (prepared otherwise) and turmeric gets synergistically enhanced for the turmeric-stabilized/encapsulated metallic NPs. Turmeric powder has good potential to reduce metal salts into elemental metal. In hydrothermal method of synthesis of silver-NP, turmeric extract is added into silver nitrate solution at high temperature to obtain highly monodispersed turmeric-stabilized AgNPs. The size of the prepared AgNPs decreases with the increase of reaction time and temperature and their antibacterial activity against Escherichia coli O157:H7 and Listeria monocytogenes is found to depend on size of the particles (Nayak et al., 2017; Alsammarraie et al., 2018). Such AgNP-impregnated cotton gauze exhibits a strong antibacterial potential against Staphylococcus aureus, Streptococcus pyogenes, and Pseudomonas aeruginosa (Maghimaa and Alharbi, 2020). Copper nanoparticle (CuNP) has also been synthesized using turmeric extract as stabilizing/capping 


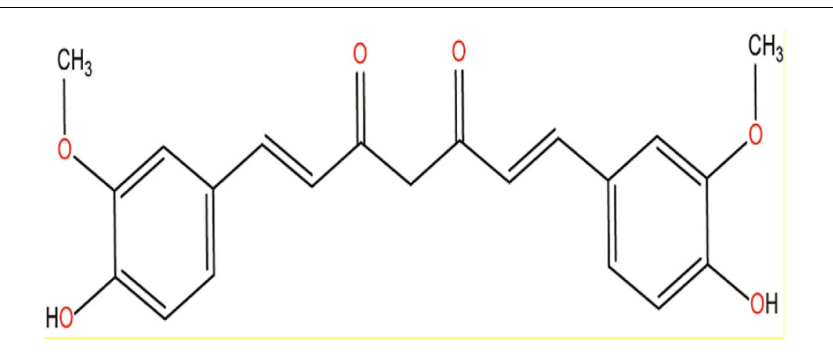

FIGURE 3 | Chemical structure of curcumin

agents. Turmeric reduces copper sulfate to elemental copper, producing highly effective CuNP. The antibacterial efficacy against Staphylococcus aureus is determined by disc diffusion on agar plate technique; turmeric-stabilized CuNP exhibits zone of inhibition of $14 \mathrm{~mm}$ size, whereas standard antibiotics like ampicillin, methicillin, and penicillin exhibit the size as 12, 10, and $11 \mathrm{~mm}$, respectively (Varghese et al., 2020).

Of the different parts of the turmeric plant, rhizome has the most pharmacological properties. Rhizome contains a number of bioactive compounds including volatile curcuminoids such as curcumin, demethoxycurcumin, and bisdemethoxycurcumin and also some volatile oils such as monoterpenoids and sesquiterpenoids (Sharifi-Rad et al., 2020). The therapeutic potentials of turmeric powder are mainly attributed to the major bioactive compound curcumin, which was first isolated in 1,870 (Sharifi-Rad et al., 2020). Curcumin is a naturally occurring yellow-orange-colored, water-insoluble, highly potent polyphenolic compound and exhibits keto-enol tautomerism, but keto form is predominant in neutral and acidic medium (Anand et al., 2007; Yang et al., 2020). The chemical structure of curcumin is shown in Figure 3.

Curcumin is widely used in multiple medicinal formulations over thousands of years because of its multi-medicinal properties such as antimicrobial, antioxidant, anti-inflammatory, anticancer, antirheumatic, cardioprotective, neuroprotective, hepatoprotective, and kidney protective roles; therefore, curcumin is universally known as the "wonder drug of life" (Yeung et al., 2019). To make the hydrophobic curcumin water soluble and to enhance its antibacterial potency, attempts have been made for its nanonization.

\section{NANO-FORMULATIONS WITH CURCUMIN}

Curcumin nanoparticles of size 2-40 $\mathrm{nm}$ have been produced by wet milling method, using curcumin, dichloromethane, and hot water. Here, curcumin in dichloromethane is sprayed into hot boiling water under sonication at room temperature to obtain a clear orange-colored solution, which is then lyophilized to powder of curcumin NP. So far as its antibacterial potency is concerned, a concentration of $400 \mu \mathrm{g} / \mathrm{ml}$ of nanocurcumin exhibits a zone of inhibition of size 12, 14, 16, and $20 \mathrm{~mm}$, whereas the equivalent concentration of free curcumin exhibits the corresponding sizes of 9, 10, 12, and $15 \mathrm{~mm}$ against Escherichia. coli, Pseudomonas aeruginosa, Staphylococcus aureus, and Bacillus subtilis, respectively (Bhawana et al., 2011; Sun et al., 2014). Curcumin NP, as solid dispersion (CSD), has been synthesized by solvent evaporation technique also. In this method, curcumin and poly (vinyl pyrolodine)-K30 are first dissolved in ethanol and then solidified by lowering the temperature to get CSD. CSD is subsequently loaded in hydrogel by simple addition of CSD into aqueous solution of surfactants P407 and P188 (Adahoun et al., 2017). CSD-loaded hydrogel gives a positive result for the treatment of injured vaginal bacterial infection caused by Staphylococcus aureus and Escherichia coli and also in the improvement of wound healing (Zhang et al., 2019). Curcumin nanoparticle is also formed by sol-gel method, where tertramethyl orthosilicate is first hydrolyzed by $\mathrm{HCl}$ and then the hydrolyzed product is added into chitosan solution of curcumin and finally the whole mixture is lyophilized to get sol-gel-based curcumin nanoparticle (Church et al., 2006). This nanoparticle is found to be highly effective against methicillinresistant Staphylococcus aureus and Pseudomonas aeruginosa (Krausz et al., 2015). Combined formulation of AgNPs and curcumin NPs, prepared by mixing AgNPs (synthesized from phytoreduction method by gallic acid; Loo et al., 2014) and curcumin NPs (synthesized from anti-solvent precipitation method by the non-ionic surfactant Pluronic-F127; Lee et al., 2015), exhibits a synergistic action on biofilm formed by drugresistant gram-positive Staphylococcus aureus and gram-negative Pseudomonas aeruginosa (Loo et al., 2016).

So far as the mechanism of antibacterial action of curcumin is concerned, it is suggested that the hydrophobic curcumin gets inserted into the membrane in a trans-bilayer fashion, being anchored by hydrogen and phosphate group of lipids and thereby disrupts cell membrane with leakage of intracellular contents (Tyagi et al., 2015). Curcumin suppresses the assembly of cytoskeleton protein FtsZ (filamentous temperature sensitive protein Z) at the junction of two daughter bacterial cells, leading to interruption of bacterial cell division and development of cell filamentation (Kaur et al., 2010). Curcumin is also found to downregulate the expression of RecA and LexA proteins, affecting the LexA-RecA pathway responsible for self-cleavage of DNA during cellular SOS DNA repair process ( $\mathrm{Li}$ et al., 2018). Furthermore, curcumin downregulates the expression of $s r c A$ and $s r c B$ genes involved in sucrose metabolism. Such low level of carbohydrate metabolism results in low secretion of polysaccharides to extracellular surface, causing loss of cellular stickiness and thus cellular ability of adherence to surfaces (Li et al., 2018).

\section{ALOE VERA}

Aloe vera plant has a long history of medicinal use, and it is very much popular for its anti-inflammatory and soothing effects on minor skin cut and burn (Cathcart and Stebbing, 2016). It is believed that the uses of aloe vera were mentioned in Rig Veda, the earliest pre-historic (about 3,000 BC) Indian corpus of natural medicine (Roy, 2011). It was also widely 


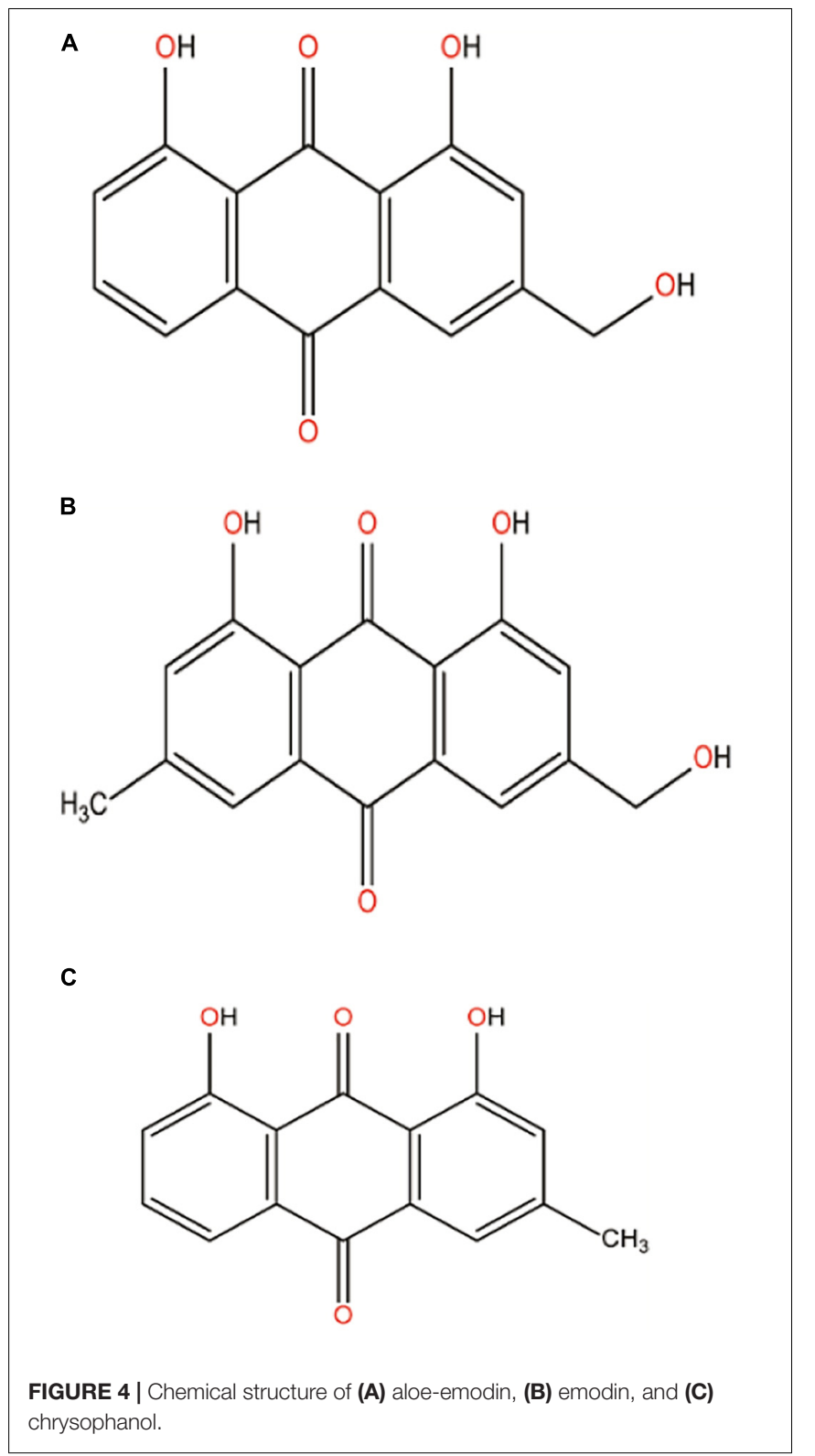

used in Egyptian, Roman, Greek, and other contemporary civilizations for medicinal purposes (Surjushe et al., 2008). Aloe vera has numerous clinical potentials like antibacterial, antifungal, antiviral, anti-inflammatory, and anticancer. It is also applied to treat psoriasis, sunburn or radiation-related dermatitis, esophagitis, allergy, rheumatic fever, rheumatoid arthritis, ulcers, and diabetes. It also lowers blood glucose level and improves the immune system (Zagora-Dziok et al., 2017).

Like other medicinal plant extracts, aloe vera extract (ALE) has also the capability of reducing silver nitrate to produce AgNPs. Antibacterial action of ALE-based AgNPs against Bacillus subtilis, Klebsiella pneumoniae, and Salmonella typhi has been measured, by the disc diffusion method, to be very effective. Such AgNPs also show promising inhibitory actions against Kocuria varians, which causes infective endocarditis, arthritis, pneumonia, peritonitis,

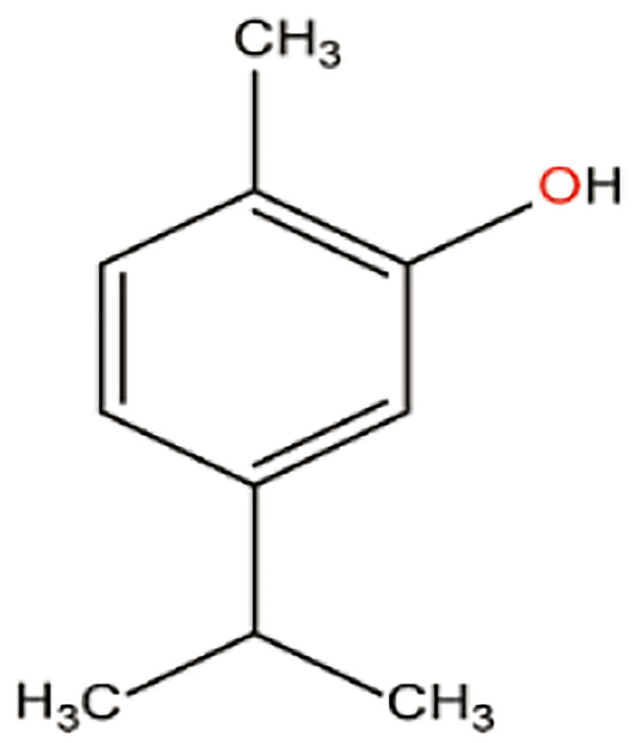

FIGURE $\mathbf{5}$ | Chemical structure of carvacrol.

hepatic abscess, catheter-associated bacteremia, canaliculitis, cholecystitis, dacryocystitis, brain abscess, and meningitis (Velez et al., 2018). ALE also reduces the aqueous solution of $\mathrm{CuNO}_{3}$ and develops brick-red-colored ALE-capped copper oxide nanoparticles (ALE-CuONPs) of size about $100 \mathrm{~nm}$, and this nanoformulation exhibits antibacterial activity against fish pathogens Aeromonas hydrophila, Pseudomonas fluorescens, and Flavobacterium branchiophilum (Vijay Kumar et al., 2015). ALE-capped iron nanoparticles (ALE-FeNPs) of size $34 \mathrm{~nm}$ can be synthesized by reduction of $\mathrm{FeCl}_{3}$ by ALE, and they are very much effective to inhibit the growth of Proteus mirabilis, Salmonella typhi, and Shigella flexneri (Yadav and Kumar, 2016). The reduction of $\mathrm{ZnSO}_{4}$ by ALE in the range of $\mathrm{pH}$ 5-10 under stirring condition produces ALE-capped zinc oxide nanoparticles ( $\mathrm{ZnONPs}$ ), which are reported to have significant antibacterial activity against extended spectrum of beta lactamase (Es $\beta \mathrm{L}$ )-positive Escherichia coli, Pseudomonas aeruginosa, and methicillin-resistant Staphylococcus aureus (Ali et al., 2016). The common way to exert bacterial toxicity by nanoparticles is generation of reactive oxygen species (ROS) and subsequent occurrence of ROS-mediated phenomena like lipid peroxidation, protein oxidation, and DNA fragmentation with ultimate termination of cellular life (Xia et al., 2008).

Aloe vera extract contains about 75 active constituents including vitamins ( $\mathrm{A}, \mathrm{C}, \mathrm{E}, \mathrm{B}_{12}$, folic acid, and choline), enzymes (alliiase, alkaline phosphatase, amylase, bradykinase, carboxypeptidase, catalase, cellulase, lipase, and peroxidase), minerals (calcium, chromium, copper, magnesium, potassium, sodium, and zinc), sugar, fatty acids, hormones, and anthraquinones. Therapeutic potentials of aloe vera is mainly attributed to the major bioactive compound class anthraquinones (Surjushe et al., 2008) and the main anthraquinones are aloeemodin (26.29\%), emodin (65.30\%), and chrysophanol $(8.41 \%)$ 


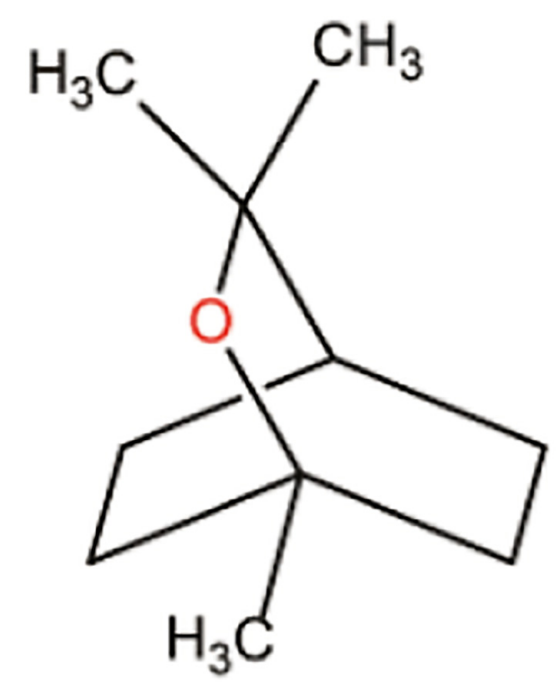

FIGURE 6 | Chemical structure of eucalyptol.

(Kang et al., 2016). These are polycyclic aromatic hydrocarbons, having chemical structures shown in Figure 4. These natural colorants are mainly used in the food industry for food packaging because of their excellent antibacterial activity. Of the three anthraquinone derivatives in aloe vera extract, since the relative concentration of emodin is considerably high compared with the other two derivatives aloe-emodin and chrysophanol, it is therefore expected that the antibacterial efficacy of the aloe vera extract is primarily due to emodin content. Apart from antibacterial activity, the compounds have multiple therapeutic potentials like laxatives, anti-inflammatory, and anticancer, and are also used to treat constipation, arthritis, and multiple sclerosis (Malik and Müller, 2016).

\section{NANOFORMULATION WITH ANTHRAQUINONE}

Anthraquinone-loaded chitosan-PLA (polylactic acid) nanoparticles (AQ-CS-PLA) are prepared by dropping method, where chitosan-PLA (CS-PLA) nanoparticles are first synthesized by simple mixing of aqueous solutions of chitosan and PLA and anthraquinone is then added into CS-PLA nanoparticles drop-wise (Dhanapal et al., 2014). Anthraquinone-loaded CS-PLA nanoparticles exhibit strong antibacterial activity against Pseudomonas aeruginosa, Klebsiella pneumoniae, Proteus vulgaris, and Escherichia coli (Dhanapal et al., 2014). No other report, so far our knowledge goes, has been found to come out on nanonization of any anthraquinone with respect to anti-bacterial action.

\section{OREGANO (Oregano vulgare)}

It is a small herb 1-3 feet long with olive-green-colored leaves and purple-colored flower. This herb belongs to the mint (Lamiaceae) family, generally found in temperate Himalayas.

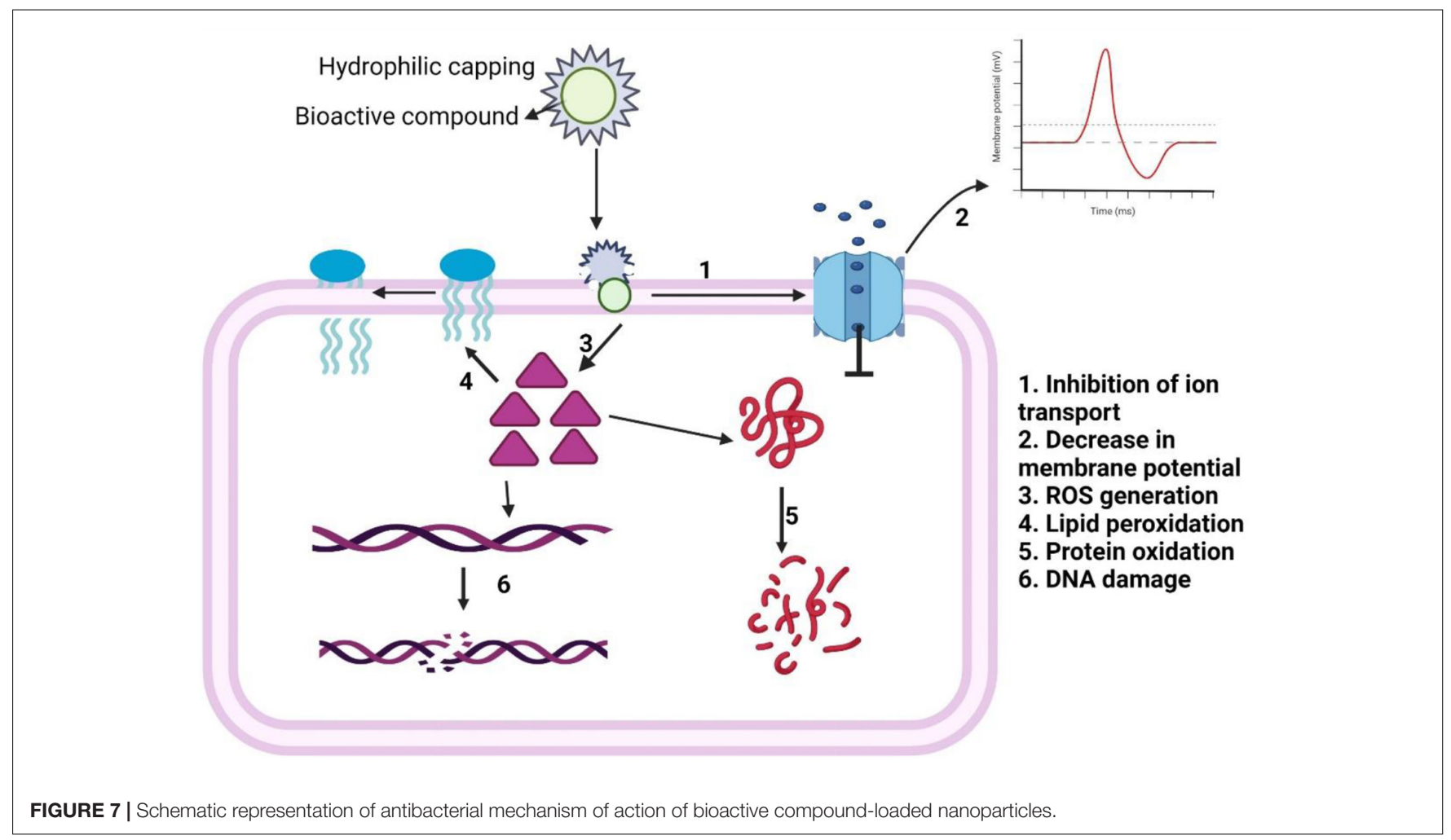


TABLE 1 | Nanonization of the major component of five different medicinal plants by different established methods of nanonization and their antibacterial potential on different bacteria.

\begin{tabular}{|c|c|c|c|c|}
\hline Major component of plant & Method of nanonization & Nanoformulation & Antibacterial action on & References \\
\hline Eugenol & $\begin{array}{l}\text { lonic gelation and Schiff base reaction } \\
\text { Solvent evaporation technique } \\
\text { Ethosome } \\
\text { Solid-lipid NPs }\end{array}$ & $\begin{array}{l}\text { Eugenol-grafted chitosan NPs } \\
\text { Eugenol-loaded PLGA NPs } \\
\text { Eugenol-loaded Zein NPs } \\
\text { Eugenol-entrapped ethosome NPs } \\
\text { Eugenol/ofloxacin Solid-lipid NPs }\end{array}$ & $\begin{array}{l}\text { S. typhimurium, } \\
\text { L. monocytogenes, } \\
\text { L. innocua, } \\
\text { A. hydrophila, } \\
\text { E. tarda, S. iniae, } \\
\text { P. aeruginosa }\end{array}$ & $\begin{array}{l}\text { Chen et al., 2009; Gomes } \\
\text { et al., 2011; Rathinam et al., } \\
\text { 2017; Jin et al., 2019; Lou } \\
\text { et al., 2019; Rodenak-Kladniew } \\
\text { et al., 2019; Luis et al., } 2020\end{array}$ \\
\hline Curcumin & $\begin{array}{l}\text { Wet milling } \\
\text { Solvent dispersion } \\
\text { Phytoreduction and anti-solvent } \\
\text { precipitation } \\
\text { Oil-in-water emulsion } \\
\text { Sol-gel method }\end{array}$ & $\begin{array}{l}\text { Curcumin NPs } \\
\text { CSD AgNPs and curcumin NPs } \\
\text { Curcumin microemulsion } \\
\text { Curcumin NPs }\end{array}$ & $\begin{array}{l}\text { E. coli, } \\
\text { P. aeruginosa } \\
\text { S. aureus, } \\
\text { B. subtilis, } \\
\text { S. epidermidis, } \\
\text { S. aureus, } \\
\text { B. subtilis, } \\
\text { P. aeruginosa }\end{array}$ & $\begin{array}{l}\text { Church et al., 2006; Kaur et al., } \\
\text { 2010; Bhawana et al., 2011; } \\
\text { Loo et al., 2014; Sun et al., } \\
\text { 2014; Krausz et al., 2015; Lee } \\
\text { et al., 2015; Yun and Lee, } \\
\text { 2016; Adahoun et al., 2017; Li } \\
\text { et al., 2018; Zhang et al., } 2019\end{array}$ \\
\hline Anthraquinone & Dropping method & AQ-CS-PLA & $\begin{array}{l}\text { P. aeruginosa, } \\
\text { K. pneumoniae, } \\
\text { P. vulgaris, } \\
\text { E. coli }\end{array}$ & Dhanapal et al., 2014 \\
\hline Carvacrol & $\begin{array}{l}\text { Solvent displacement } \\
\text { Simple mixing } \\
\text { Microemulsion }\end{array}$ & $\begin{array}{l}\text { Carvacrol-loaded PLGA NPS } \\
\text { Fabricated ovalbumin/carvacrol } \\
\text { NPs } \\
\text { Carvacrol-loaded solid-lipid } \\
\text { nanodispersion }\end{array}$ & $\begin{array}{l}\text { S. epidermidis, } \\
\text { S. sp. } \\
\text { B. cereus } \\
\text { E. coli O157:H7 } \\
\text { P. aeruginosa } \\
\text { S. aureus }\end{array}$ & $\begin{array}{l}\text { lannitelli et al., 2011; He et al., } \\
\text { 2019; Mir et al., 2020; Rao } \\
\text { et al., } 2020\end{array}$ \\
\hline Eucalyptus oil & $\begin{array}{l}\text { Sonication cavitation } \\
\text { Impregnated nanoemulsion } \\
\text { Nanoemulsion }\end{array}$ & $\begin{array}{l}\text { Eucalyptus oil nanoemulsion } \\
\text { Eugenol-impregnated chitosan } \\
\text { nanoemulsion } \\
\text { Eucalyptus oil nanoemulsion }\end{array}$ & $\begin{array}{l}\text { L. monocytogenes } \\
\text { S. aureus } \\
\text { E. coli } \\
\text { B. cereus }\end{array}$ & $\begin{array}{l}\text { Sugumar et al., 2014; } \\
\text { Chandrasekaran, 2015; } \\
\text { Lopez-Romero et al., 2015; } \\
\text { Quatrin et al., } 2017\end{array}$ \\
\hline
\end{tabular}

Both fresh and dry leaves are used in kitchen because of its refreshing flavor and fragrance, which make the recipe more delicious. This herb is also very much common in Greek, Roman, and Mediterranean diet from ancient period. The uses of oregano have been explored worldwide in very recent times after the evaluation of its medicinal properties. In traditional folk medicine, oregano is used to treat microbial infections like colic, cough, headache, and toothaches. It is also used to treat nervousness and irregular menstrual cycle (Leyva-Lopez et al., 2017). Oregano extract contains many phytochemicals, most of which are essential oils such as carvacrol, thymol, $\gamma$-terpenene, p-cymene, linalool, terpinene-4-ol, $\beta$-myrcene, trans-sabinene hydrate, and $\beta$-caryophyllene (Leyva-Lopez et al., 2017). Essential oils of oregano are extremely popular for fragrance and for their excellent antimicrobial properties; they also have various other pharmacological activities such as highly antioxidant, antiinflammatory, cardio-protective, and metabolism aids (LeyvaLopez et al., 2017).

Oregano leaf extract (OLE) has been used to produce silver-NP by hot hydrothermal method, where silver nitrate is reduced to metallic silver by the antioxidant property of OLE, and these OLE-stabilized silver nanoparticles (OLEAgNPs) show high antibacterial activity against Pseudomonas aeruginosa and Staphylococcus aureus (Meretoudi et al., 2021). Gold nanoparticles (AuNPs) can also be prepared with the help of polyethylene glycol (PEG) and oregano extract. During nanoformulation, $\mathrm{HAuCl}_{4}$ is used as precursors and OLE as indicator whereas PEG is used as both reducing and capping agents. In presence of $\mathrm{Au}^{3+}$, oregano extract gives an indicative ruby red color to the nanoformulation OLE-AuNPs. Oregano synergizes the antibacterial potential of AuNPs, and OLEAuNPs act as effective antibacterial against gram-positive bacteria Staphylococcus aureus ATCC 6538P, Listeria monocytogenes ATCC13932 as well as gram-negative bacteria Salmonella enteritidis ATCC 13076 and Escherichia coli ATCC 25922, when determined by disc diffusion method (Benedec et al., 2018). Nanonization of oregano oil has been made by the "oil in water" nanoemulsion method by simply mixing oregano oil and the surfactant Tween 80 in water in 2:1 ratio, followed by sonication for $10 \mathrm{~min}$, and this nanoformulation is found to control foodborne bacterial pathogens Listeria monocytogenes ATCC 19115, Salmonella typhimurium ATCC 19585, and Escherichia coli O157:H7 ATCC 700927 on lettuce leaves (Bhargava et al., 2015). Nanoemulsion of oregano oil has also been synthesized by phase inversion method, where different amounts of oregano oil and surfactant in water are mixed and then subjected to heating/cooling cycle twice to encapsulate oregano oil within surfactant. The droplet size of nanoemulsion depends on the amount of oil. Such nanoemulsion of oregano oil has significant antibacterial activity on Staphylococcus aureus and Escherichia coli and may be used as food preservative (Moraes-Lovison et al., 2017). The nanoemulsion-incorporated hydroxypropyl methyl cellulose-based active nanocomposite exhibits strong antioxidant and antibacterial properties against Salmonella sp. (Lee et al., 2019). Oregano extract inhibits bacterial attachment, motility, and production of a virulent factor "shiga toxin" by 

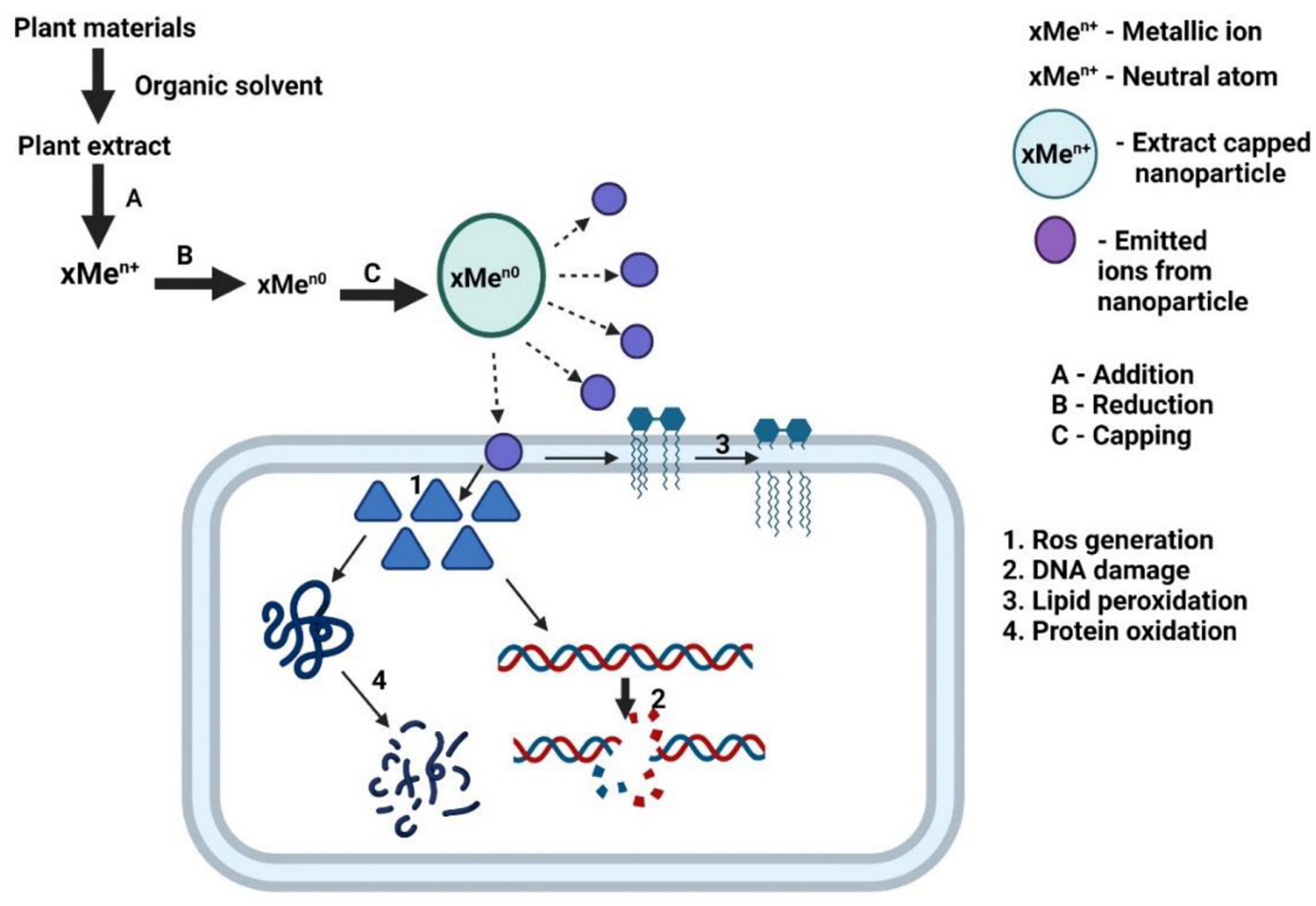

\section{Ros generation \\ 2. DNA damage \\ 3. Lipid peroxidation \\ 4. Protein oxidation}

FIGURE 8 | Schematic representation of antibacterial mechanism of action of plant extract stabilized metallic nanoparticle.

downregulating the expression of the corresponding genes ler, fliC, and stx2B in Escherichia coli EHEC O157:H7 (Barbosa et al., 2020). Oregano oils weaken the cellular membrane leading to leakage of small molecules such as $\mathrm{Na}^{+}, \mathrm{K}^{+}, \mathrm{Ca}^{2+}, \mathrm{H}^{+}$, and $\mathrm{Cl}^{-}$and thereby causing inhibition of membrane coupled energy production and finally cell death (Mith et al., 2015).

Oregano leaf extract contains principally essential oils. Oregano essential oils are carvacrol, $\beta$-fenchyl alcohol, thymol, and $\gamma$-terpenine. Therapeutic potentials of oregano are mainly attributed to its major component carvacrol, which belongs to phenolic monoterpenoid compound (Leyva-Lopez et al., 2017; Figure 5), found mainly in oregano, thyme, and peppermint plants (Sharifi-Rad et al., 2018). This compound possesses numerous biological activities including antibacterial, antifungal, antiviral, anticancer, antigenotoxic, antispasmodic, anti-inflammatory, antiparasitic, anti-elastase, hepatoprotective, AChe inhibitory, and food additives (Baser, 2008). Carvacrol is very much popular in the food industry due to its flavor and significant antibacterial activities (Ozkan et al., 2017). The hydrophobic nature of carvacrol led to the synthesis of its nano-form to develop its aqueous solubility and therefore bioavailability (Figure 5).

\section{NANOFORMULATION WITH CARVACROL}

Carvacrol-loaded PLGA nanoparticles have been prepared by solvent displacement method. In this method, PLGA, surfactant epikuron, and carvacrol are first dissolved in acetone; the mixture is then added into aqueous solution of another surfactant pluronic F65 and the whole mixture is finally concentrated by applying pressure to obtain carvacrol-loaded nanoparticles. PLGA acts as a capping agent while both surfactants are used as stabilizing agents to prepare carvacrol-loaded nanoparticles, which are found to possess strong antibiofilm activities formed by Staphylococcus epidermidis ATCC 35984 (Iannitelli et al., 2011). Carvacrol-loaded ovalbumin gel nanoparticles are developed by mixing egg white with carvacrol, heating the mixture for $30 \mathrm{~min}$ at $90^{\circ} \mathrm{C}$, followed by immediate cooling in an ice bath; the prepared gel is finally mixed by stirring to achieve fabricated and homogenized ovalbumin-carvacrol gel nanoparticles. This nanoformulation displays a promising antibacterial activity against Salmonella sp. and Bacillus cereus (Rao et al., 2020). Synthesis of carvacrol-loaded solid-lipid nanodispersion has been made by microemulsion template method, where lipid phase contains propylene glycol monopalmitate, glycerol monosterate, and carvacrol whereas aqueous phase contains Tween 80; the lipid phase is added dropwise into aqueous phase under continuous stirring to form a transparent microemulsion. This solid-lipid nanodispersion is very much effective to inhibit the growth of gram-negative Escherichia coli O157:H7 and grampositive Staphylococcus aureus (He et al., 2019). Carvacrolloaded polycaprolactone (PCL) nanoparticles are prepared by nanoprecipitation method. Polymer PCL is dissolved in acetone, carvacrol is then added into PCL solution with mild heating, and the mixture is then added into aqueous phase of surfactant polaxamer followed by homogenization and centrifugation. This 
nanoformulation is found to be effective against Pseudomonas aeruginosa and Staphylococcus aureus (Mir et al., 2020).

The promising antibacterial activity of carvacrol is attributed to the permeabilization and depolarization of cell membrane (Xu et al., 2008). Carvacrol exhibits rapid bactericidal activity against pathogens like Escherichia coli and Streptococcus pyogenes through cell membrane damage and consequent inhibition of some cellular processes like syntheses of DNA and lipid, and leakage of cytoplasmic content such as lactate dehydrogenase enzymes and nucleic acids (Wijesundara et al., 2021). It is also reported that carvacrol (1) penetrates the bacterial cell membrane easily in Listeria monocytogenes, (2) changes the composition of fatty acids that affects membrane fluidity and permeability, (3) causes a decrease in membrane polarity and inhibition of cellular respiratory activity (Churklam et al., 2020), (4) reduces the expression of virulent enterotoxin in Staphylococcus aureus by controlling the complex regulatory network (Zhang et al., 2020), and (5) decreases motility in Salmonella typhimurium with loss of functionality of flagellum (Zhang et al., 2020).

\section{EUCALYPTUS (Eucalyptus globulus)}

The term eucalyptus was first given and described by French botanist L'Heritier. It is a woody, perennial, and mostly evergreen plant and grows well in deep, fertile, well-drained loamy soil with adequate moisture (Acharya and Acharya, 2019). Eucalyptus is widely used in traditional medicine for its versatile and excellent pharmacological properties. Because of its anti-septic and antispasmodic properties, it is mainly used to treat respiratory complications such as bronchitis, asthma, lower respiratory tract infections, and chronic obstructive pulmonary diseases (Horváth and Ács, 2015). It also increases blood flow and skin temperature (Hayat et al., 2015). Eucalyptus extract also exhibits antiinflammatory, antibacterial, anticancer, and astringent activities (Sulaiman et al., 2013). For its excellent therapeutic activities, leaf and bark extracts of eucalyptus plant have been nanonized by different methods.

It is reported that eucalyptus leaf extract (ELE) produces metallic AgNPs on shaking with silver nitrate solution in a gyratory shaker incubator at $150 \mathrm{rpm}$ and at $28^{\circ} \mathrm{C}$ in the dark for $16 \mathrm{~h}$. The prepared AgNPs inhibit the growth of multidrug-resistant Acinetobacter baumannii isolated from a pneumonia patient (Wintachai et al., 2019). These AgNPs have effective antibacterial activity against pathogenic bacteria Pseudomonas aeruginosa, Escherichia coli, Staphylococcus aureus, and Bacillus subtilis also (Sulaiman et al., 2013). ELE-stabilized AgNPs have also been developed by microwave-assisted technique. In this process, ELE and $\mathrm{AgNO}_{3}$ are mixed in a conical flask and then subjected to microwave treatment in a domestic microwave oven operating at a power of $8,000 \mathrm{~W}$ and frequency $2,450 \mathrm{MHz}$ for a short pulse of $30 \mathrm{~s}$. Such AgNPs have antibacterial and antibiofilm potentials against Escherichia coli and Staphylococcus aureus (MRSA and MSSA) (Ali et al., 2019). ELE has the potential to reduce $\mathrm{Cu}\left(\mathrm{NO}_{3}\right)_{2}$ also, producing $\mathrm{CuO}-\mathrm{NPs}$ of size about $27.2 \mathrm{~nm}$, and the particles show excellent inhibitory effect on bacterial biofilm formation (Ali et al., 2015). Not only biofilm cells, ELEstabilized CuONPs are also more effective than commercially available bulk $\mathrm{CuO}$ molecules to kill even the planktonic cells of $\beta$-lactamase-producing Escherichia coli 336, Pseudomonas aeruginosa 621, and methicillin-resistant Staphylococcus aureus 1 (Shanan et al., 2018). By the method of phytoreduction, ELE also produces nickel oxide nanoparticles (NiO-NPs) from the precursor nickel hexahydrate $\left(\mathrm{NiNO}_{3} \cdot 6 \mathrm{H}_{2} \mathrm{O}\right)$. These $\mathrm{NiO}-\mathrm{NPs}$ exhibit antibacterial and antibiofilm potential against Es $\beta$ L-producing Escherichia coli, Pseudomonas aeruginosa, and methicillin-resistant and sensitive Staphylococcus aureus (Saleem et al., 2017).

ELE comprises various compounds, of which essential oils are the major part. All the essential oils are collectively termed as eucalyptus oil, which includes eucalyptol (1,8-cineole), $p$-cymene, $\alpha$-pinene, $\beta$-myrcene, and $\gamma$-terpinene. Eucalyptol is the major oil component in eucalyptus oil, with the chemical structure shown in Figure 6. The therapeutic potential of ELE is mainly attributed to the bioactive components-eucalyptus oils (Almas et al., 2021). Due to its excellent pharmacological profile, nanoformulation of eucalyptus oil has been made to increase both its bioavailability and pharmacological profile.

\section{NANOFORMULATION WITH EUCALYPTUS OIL}

Nanoemulsion of eucalyptus oil (cineole: 60\%) is prepared by sonicating a mixture of eucalyptus oil, Tween 80 , and water. The amplitude and sonication time determine the particle size of nanoemulsion. This nanoformulation significantly reduces the population of clinical pathogen Staphylococcus aureus and has wound healing activity in Wistar rats (Sugumar et al., 2014). Eucalyptus oil-impregnated chitosan nanoparticle has been found to have more antibacterial potency, compared with free oil, against clinical pathogen Staphylococcus aureus (Sugumar et al., 2015). Eucalyptus oil nanoemulsion, synthesized by spontaneous emulsification, which involves simply mixing water into heated organic phase containing eucalyptus oil and surfactant Tween 20 under stirring condition at $400 \mathrm{rpm}$, is also effective to stop the growth of gram-negative pathogen Listeria monocytogenes MTCC 1143 (Chandrasekaran, 2015) and different foodborne pathogens such as Escherichia coli, Staphylococcus aureus, and Bacillus cereus (Pathania et al., 2018). Well-dispersed nanoemulsion of eucalyptus oil has also been prepared by using double surfactants, where the oil phase containing oil and one surfactant sorbitan monooleate is injected into the aqueous phase containing the other surfactant Tween 80, under stirring condition with controlled temperature in an ice bath. This nanoemulsion is very much efficient to stop the growth of Pseudomonas aeruginosa (Quatrin et al., 2017).

The exact antibacterial mechanism of eucalyptus oil is not yet fully understood. Exposure of oil increase bacterial cell surface hydrophobicity. As essential oils are hydrophobic in nature, the increased hydrophobicity in cell surface easily allows oil to penetrate the membrane. The oils destabilize the membrane 
TABLE 2 | Green synthesis of different metal and metal oxide NPs, using five different medicinal plant extracts and different established methods of nanonization, having antibacterial potential on different bacteria.

\begin{tabular}{|c|c|c|c|c|c|}
\hline Name of the plant & Method of nanonization & Precursor metallic solution & Nanoformulation & Antibacterial action on & References \\
\hline Tulsi & Phytoreduction & $\mathrm{AgNO}_{3}$ & AgNPs & $\begin{array}{c}\text { E. coli, } \\
\text { S. aureus, } \\
\text { K. pneumoniae, } \\
\text { B. linens, } \\
\text { P. acnes, } \\
\text { B. cereus, } \\
\text { S. epidermidis }\end{array}$ & $\begin{array}{l}\text { Ramteke et al., 2013; Durán } \\
\text { et al., 2016; Ramkumar et al., } \\
\text { 2017; Khorrami et al., 2018; } \\
\text { Jacob et al., 2019; Yin et al., } \\
2020\end{array}$ \\
\hline Turmeric & Phytoreduction & $\begin{array}{l}\mathrm{AgNO}_{3} \\
\mathrm{CuSO}_{4}\end{array}$ & $\begin{array}{l}\text { AgNPs } \\
\text { CuNPs }\end{array}$ & $\begin{array}{c}\text { E. coli } \\
\text { O157:H7, } \\
\text { L. monocytogenes, } \\
\text { B. subtilis, } \\
\text { P. aeruginosa, } \\
\text { S. aureus }\end{array}$ & $\begin{array}{c}\text { Nayak et al., 2017; } \\
\text { Alsammarraie et al., 2018; } \\
\text { Maghimaa and Alharbi, 2020; } \\
\text { Varghese et al., } 2020\end{array}$ \\
\hline Aloe vera & Phytoreduction & $\begin{array}{l}\mathrm{AgNO}_{3} \\
\mathrm{CuSO}_{4} \\
\mathrm{FeCl}_{3} \\
\mathrm{ZnSO}_{4}\end{array}$ & $\begin{array}{l}\text { AgNPs } \\
\text { CuONPs } \\
\text { FeNPs } \\
\text { ZnONPs }\end{array}$ & $\begin{array}{c}\text { E. coli, } \\
\text { P. aeruginosa, } \\
\text { B. subtilis, } \\
\text { K. pneumoniae, } \\
\text { S. typhi, } \\
\text { K. varians, } \\
\text { A. hydrophila, } \\
\text { P. fluorescens, } \\
\text { F. branchiophilum, } \\
\text { P. mirabilis, } \\
\text { S. flexneri }\end{array}$ & $\begin{array}{l}\text { Xia et al., 2008; Vijay Kumar } \\
\text { et al., 2015; Ali et al., 2016; } \\
\text { Yadav and Kumar, 2016; Velez } \\
\text { et al., } 2018\end{array}$ \\
\hline Oregano & $\begin{array}{l}\text { Hot hydrothermal method } \\
\text { PEG stabilization }\end{array}$ & $\begin{array}{l}\mathrm{AgNO}_{3} \\
\mathrm{HAuCl}_{4}\end{array}$ & $\begin{array}{l}\text { AgNPs } \\
\text { AuNPs }\end{array}$ & $\begin{array}{l}\text { P. aeruginosa } \\
\text { S. aureus } \\
\text { S. enteritidis }\end{array}$ & $\begin{array}{l}\text { Bhargava et al., 2015; Mith } \\
\text { et al., 2015; Moraes-Lovison } \\
\text { et al., 2017; Benedec et al., } \\
\text { 2018; Lee et al., 2019; } \\
\text { Meretoudi et al., } 2021\end{array}$ \\
\hline Eucalyptus & Phytoreduction & $\begin{array}{c}\mathrm{AgNO}_{3} \\
\mathrm{CuSO}_{4} \\
\mathrm{NiNO}_{3} \cdot 6 \mathrm{H}_{2} \mathrm{O}\end{array}$ & $\begin{array}{l}\text { AgNPs } \\
\text { CuONPs } \\
\text { NiONPs }\end{array}$ & $\begin{array}{l}\text { P. aeruginosa, } \\
\text { E. coli, } \\
\text { S. aureus, } \\
\text { B. subtilis }\end{array}$ & $\begin{array}{c}\text { Sulaiman et al., 2013; Saleem } \\
\text { et al., 2017; Ali et al., 2019; } \\
\text { Wintachai et al., } 2019\end{array}$ \\
\hline
\end{tabular}

phospholipid bilayer and thus affects various cellular processes, finally causing cell death (Lopez-Romero et al., 2015).

\section{CONCLUSION}

For thousands of years, natural products have been used to treat various bacterial infections all over the world. Historically, the major contribution in pharmacotherapy and medicine arrived from different medicinal plant products and their structural analogs. However, natural plant products present some technical and biological challenges for being developed as drugs. The technical challenges are barriers to screen the active ingredients of plant extracts through isolation, characterization, and optimization, whereas the biological challenges are their less bioavailability for low aqueous solubility and lack of scientific research outputs on the mechanism of their specific biological actions. For these challenges, pharmaceutical industries decline their interest to pursue natural products as drugs; instead, their R\&D emphasis rallied toward chemically synthesized counterparts. Some recent technological and scientific developments on improved analytical tools like GC-MS, (LC-MS)-MS, and NMR spectroscopy fade out the technical challenges, whereas the use of various strategies of nanotechnology makes the plants' components more bioavailable and more potentially bioactive. Therefore, modern scientific and technological developments vitalize the bioactive components of medicinal plants to evolve out as a new platform of drug development and drug delivery. The combination of natural product and nanotechnology will gradually evolve out nanonaturopathic antibacterial drugs, which have advantageous features such as multiple mechanisms of action, lower possibility of interaction with a particular biomolecule (as in case of antibiotic) and therefore less tendency to induce bacterial resistance, biocompatibility and no cytotoxicity at scheduled dose, less side effects, and better therapeutic potentials due to enhanced surface area to volume ratio of the nanonized plant products, over the bulk form of the same natural products. The gross molecular mechanism of antibacterial action of the nanonized bioactive compounds of medicinal plants, as summarized in Figure 7, can be suggested as follows: the medicinal phytochemicals being lipophilic in nature bind to bacterial cell membrane, causing loss of membrane integrity with consequent decrease of membrane potential, ion transport, and energy production, which in result induces and enhances cellular ROS level that lead to subsequent lipid peroxidation, protein oxidation, DNA damage, and finally cell death. Fundamental understanding on the mechanism of antibacterial action in more 
molecular detail, through studies on up-/downregulation of bacterial genes, proteins, and metabolites, is yet to be attained and toward which future research should be directed. Table 1 contains the overall extract of information, transpired in this review, about the major phytochemicals of the five different medicinal plants, their nanonization by different established methods, and their target bacteria.

In addition to the nanoformulation of the major plant components, use of the plants' crude extract as reducing/stabilizing/capping agent (s) for preparing different metallic and metal oxide NPs and the antibacterial efficacy of these NPs have also been described in this review. The gross mechanism of antibacterial action of these green synthesized metallic NPs, as summarized in Figure 8, can be interpreted as follows: the plant whole extracts containing different phytochemicals, being a good antioxidant, tend to reduce metal salts to zero-valent metallic NPs, which may further be stabilized and/or capped by the phytochemicals; the NPs, when added in bacterial culture medium, are oxidized and emit metal ions, which cause an increase in cellular ROS level leading to cellular lipid peroxidation, protein oxidation, DNA damage, and ultimately cell death. Table 2 shows a consolidated view of this review coverage on synthesis of different metal and metal oxide NPs, using the five different medicinal plant extracts through different established methods of nanonization and the target bacteria of the NPs.

\section{REFERENCES}

Acharya, K., and Acharya, K. (2019). Insights into Eucalyptus genus chemical constituents, biological activities and health-promoting effects. Trends Food Sci. Technol. 91, 609-624. doi: 10.1016/j.tifs.2019.08.003

Adahoun, M. A., Al-Akhras, M.-A. H., Jaafar, M. S., and Bououdina, M. (2017). Enhanced anti-cancer and antimicrobial activities of curcumin nanoparticles. Artif Cells Nanomed. Biotechnol. 45, 98-107. doi: 10.3109/21691401.2015. 1129628

Adonizio, A., Kong, K.-F., and Mathee, K. (2008). Inhibition of Quorum SensingControlled Virulence Factor Production in Pseudomonas aeruginosa by South Florida Plant Extracts. Antimicrob. Agents Chemother. 52, 198-203. doi: 10. 1128/AAC.00612-07

Ali, K., Ahmed, B., Ansari, S. M., Saquib, Q., Al-Khedhairy, A. A., Dwivedi, S., et al. (2019). Comparative in situ ROS mediated killing of bacteria with bulk analogue, Eucalyptus leaf extract (ELE)-capped and bare surface copper oxide nanoparticles. Mater Sci. Eng. C Mater Biol. Appl. 100, 747-758. doi: 10.1016/j. msec.2019.03.012

Ali, K., Ahmed, B., Dwivedi, S., Saquib, Q., Al-Khedhairy, A. A., and Musarrat, J. (2015). Microwave accelerated green synthesis of stable silver nanoparticles with Eucalyptus globulus leaf extract and their antibacterial and antibiofilm activity on clinical isolates. PLoS One 10:e0131178. doi: 10.1371/journal.pone. 0131178

Ali, K., Dwivedi, S., Azam, A., Saquib, Q., Al-Said, M. S., Alkhedhairy, A. A., et al. (2016). Aloe vera extract functionalized zinc oxide nanoparticles as nanoantibiotics against multi-drug resistant clinical bacterial isolates. J. Colloid Interf. Sci. 472, 145-156. doi: 10.1016/j.jcis.2016.03.021

Almas, I., Innocent, E., Machumi, F., and Kisinza, W. (2021). Chemical composition of essential oils from Eucalyptus globulus and Eucalyptus maculata grown in Tanzania. Sci. Afr. 12:e00758. doi: 10.1016/j.sciaf.2021.e0 0758

Alsammarraie, F. K., Wang, W., Zhou, P., Mustapha, A., and Lin, M. (2018). Green synthesis of silver nanoparticles using turmeric extracts and investigation
So far as our knowledge goes, there is hardly any report to this date on nanonization of whole extract of any medicinal plant organ through encapsulation or entrapment within any capping agent or nanocarrier. In this regard, our venture of nanonization of Ocimum sanctum leaf extract, using gelatin as the capping agent, is highly inspiring so far as the role of the nanoformulation against renal lithiasis and bacteriofilm disorders is concerned (unpublished results).

\section{AUTHOR CONTRIBUTIONS}

SG: manuscript preparation, information collection, and picture preparation. SN: information collection. TB: revision and final manuscript preparation. All authors contributed to the article and approved the submitted version.

\section{FUNDING}

We are indebted to (1) UGC-GOI for supporting SG with fellowship and contingency grant, (2) DBT-GOI for supporting $\mathrm{SN}$ with fellowship under project no. BT/PR28288/NNT/28/1558/2018, and (3) DST-GOI for its "FIST" [SR/FST/LSI-623/2014(C)] and "PURSE" [SR/PURSE Phase 2/37(G)] Programs and UGC-GOI for its DRS(II)SAP [F.5-3/2018/DRS-II(SAPII)], for providing different instrumental and infrastructural supports.

of their antibacterial activities. Colloids Surf. B Biointerfaces 1, 398-405. doi: 10.1016/j.colsurfb.2018.07.059

Anand, P., Kunnumakkara, A. B., Newman, R. A., and Aggarwal, B. B. (2007). Bioavailability of curcumin: problems and promises. Mol. Pharm. 4, 807-818. doi: $10.1021 / \mathrm{mp} 700113 \mathrm{r}$

Barbosa, L. N., Alves, F. C. B., Andrade, B. F. M. T., Albano, M., Rall, V. L. M., Fernandes, A. A. H., et al. (2020). Proteomic analysis and antibacterial resistance mechanisms of Salmonella Enteritidis submitted to the inhibitory effect of Origanum vulgare essential oil, thymol and carvacrol. J. Proteom. 214:103625. doi: 10.1016/j.jprot.2019.10 3625

Baser, K. H. C. (2008). Biological and pharmacological activities of carvacrol and carvacrol bearing essential oils. Curr. Pharm. Des. 14, 3106-3119. doi: 10.2174/ 138161208786404227

Benedec, D., Oniga, I., Cuibus, F., Sevastre, B., Stiufiuc, G., Duma, M., et al. (2018). Origanum vulgare mediated green synthesis of biocompatible gold nanoparticles simultaneously possessing plasmonic, antioxidant and antimicrobial properties. Int. J. Nanomed. 13, 1041-1058. doi: 10.2147/IJN. S149819

Bhan, M. K., Bahl, R., and Bhatnagar, S. (2005). Typhoid and paratyphoid fever. Lancet 366, 749-762. doi: 10.1016/S0140-6736(05)67181-4

Bhargava, K., Conti, D. S., da Rocha, S. R. P., and Zhang, Y. (2015). Application of an oregano oil nanoemulsion to the control of foodborne bacteria on fresh lettuce. Food Microbiol. 47, 69-73. doi: 10.1016/j.fm.2014.1 1.007

Bhargava, K. P., and Singh, N. (1981). Anti-stress activity of Ocimum sanctum Linn. Indian J. Med. Res. 73, 443-451.

Bhawana, N., Basniwal, R. K., Buttar, H. S., Jain, V. K., and Jain, N. (2011). Curcumin nanoparticles: preparation, characterization, and antimicrobial study. J. Agric. Food Chem. 59, 2056-2061. doi: 10.1021/jf104 $402 \mathrm{t}$

Bjarnsholt, T. (2013). The role of bacterial biofilms in chronic infections. APMIS Suppl. 2013, 1-51. doi: 10.1111/apm.12099 
Cathcart, P., and Stebbing, J. (2016). Aloe vera, a natural cancer soother? Lancet Oncol. 17, 421. doi: 10.1016/S1470-2045(16)00161-3

Chandrasekaran, D. N. (2015). Nanoemulsion formation and characterization by spontaneous emulsification: Investigation of its antibacterial effects on Listeria monocytogenes. Asian J. Pharm. 9, 23-28. doi: 10.22377/ajp.v9i 1.427

Chen, F., Shi, Z., Neoh, K. G., and Kang, E. T. (2009). Antioxidant and antibacterial activities of eugenol and carvacrol-grafted chitosan nanoparticles. Biotechnol. Bioeng. 104, 30-39. doi: 10.1002/bit.22363

Church, D., Elsayed, S., Reid, O., Winston, B., and Lindsay, R. (2006). Burn wound infections. Clin. Microbiol. Rev. 19, 403-434. doi: 10.1128/CMR.19.2.403-434. 2006

Churklam, W., Chaturongakul, S., Ngamwongsatit, B., and Aunpad, R. (2020). The mechanisms of action of carvacrol and its synergism with nisin against Listeria monocytogenes on sliced bologna sausage. Food Control 108:106864. doi: 10.1016/j.foodcont.2019.106864

Das, N., and Chandran, P. (2011). Microbial degradation of petroleum hydrocarbon contaminants: an overview. Biotechnol. Res. Int. 2011:941810. doi: 10.4061/2011/941810

Das, S. K., and Vasudevan, D. M. (2006). Tulsi: the Indian holy power plant. Nat. Prod. Radiance 5, 279-283.

Dhanapal, J., Malathy, B. R., Pradeep, S. P., and Seshadri, S. (2014). Antibacterial activity of anthraquinone encapsulated chitosan/poly(lactic acid) nanoparticles. Internat. J. Pharm. Bio Sci. 5, 20-28.

Doron, S., and Gorbach, S. L. (2006). Prebiotics: their role in the treatment and prevention of diseases. Expert Rev. Anti Infect. Ther. 4, 261-275. doi: 10.1586/ 14787210.4.2.261

Dubey, S. P., Lahtinen, M., Sarkka, H., and Silanpaa, M. (2010). Bioprospective of Sorbus aucuparia leaf extract in development of silver and gold nanocolloids. Colloids Surf. B Biointerfaces 80, 26-33. doi: 10.1016/j.colsurfb.2010.05.024

Durán, N., Nakazato, G., and Seabra, A. B. (2016). Antimicrobial activity of biogenic silver nanoparticles, and silver chloride nanoparticles: an overview and comments. Appl. Microbiol. Biotechnol. 100, 6555-6570. doi: 10.1007/s00253016-7657-7

Gill, A. O., and Holley, A. R. (2004). Mechanisms of bactericidal action of cinnamaldehyde against Listeria monocytogenes and of eugenol against L. monocytogenes and Lactobacillus sakei. Appl. Environ. Microbiol. 70, 57505755. doi: 10.1128/AEM.70.10.5750-5755.2004

Gomes, C., Moreira, R. G., and Castell-Perez, E. (2011). Poly (DL-lactide-coglycolide) (PLGA) nanoparticles with entrapped trans-cinnamaldehyde and eugenol for antimicrobial delivery applications. J. Food Sci. 76, N16-N24. doi: 10.1111/j.1750-3841.2010.01985.x

Gupta, S. K., Prakash, J., and Srivastava, S. (2002). Validation of traditional claim of Tulsi, Ocimum sanctum Linn. as a medicinal plant. Indian J. Exp. Biol. 40, 765-773.

Hayat, U., Jilani, M. I., Rehman, R., and Nadeem, F. (2015). A review on Eucalyptus globulus: a new perspective in therapeutics. Int. J. Chem. Biochem. Sci. 8, 85-91.

He, J., Huang, S., Sun, X., Han, L., Chang, C., Zhang, W., et al. (2019). Carvacrol Loaded Solid Lipid Nanoparticles of Propylene Glycol Monopalmitate and Glyceryl Monostearate: Preparation, Characterization, and Synergistic Antimicrobial Activity. Nanomaterials 9:1162. doi: 10.3390/nano9081162

Hill, D. A., and Artis, D. (2010). Intestinal bacteria and the regulation of immune cell homeostasis. Annu. Rev. Immunol. 28, 623-667. doi: 10.1146/annurevimmunol-030409-101330

Horváth, G., and Ács, K. (2015). Essential oils in the treatment of respiratory tract diseases highlighting their role in bacterial infections and their antiinflammatory action: a review. Flavour Fragr. J. 30, 331-341. doi: 10.1002/ffj. 3252

Iannitelli, A., Grande, R., Di Stefano, A., Di Giulio, M., Sozio, P., Bessa, L. J., et al. (2011). Potential antibacterial activity of carvacrol-loaded Poly(DL-lactide-coglycolide) (PLGA) nanoparticles against microbial biofilm. Int. J. Mol. Sci. 12, 5039-5051. doi: 10.3390/ijms12085039

Jacob, J. M., John, M. S., Jacob, A., Abitha, P., Kumar, S. S., Rajan, R., et al. (2019). Bactericidal coating of paper towels via sustainable biosynthesis of silver nanoparticles using Ocimum sanctum leaf extract. Mater. Res. Express 6:045401.

Jayachandran, A., Aswathy, T. R., and Nair, A. S. (2021). Green synthesis and characterization of zinc oxide nanoparticles using Cayratia pedata leaf extract. Biochem. Biophys. Rep. 26:100995. doi: 10.1016/j.bbrep.2021.100995
Jin, P., Yao, R., Qin, D., Chen, Q., and Du, Q. (2019). Enhancement in Antibacterial Activities of Eugenol-Entrapped Ethosome Nanoparticles via Strengthening Its Permeability and Sustained Release. J. Agric. Food Chem. 67, 1371-1380. doi: 10.1021 acs.jafc. 8 b06278

Kang, S., Zhao, X., Yue, L., and Liu, L. (2016). Main anthraquinone component in Aloe vera and their inhibitory effects on the advanced glycation end-products. J. Food Process. Preserv. 41:e13160. doi: 10.1111/jfpp.13160

Kasi, P. D., Nisha, S. A., Ravi, S., and Pandian, S. K. (2010). Eugenol (an essential oil of clove) acts as an antibacterial agent against Salmonella typh $i$ by disrupting the cellular membrane. J. Ethnopharmacol. 130, 107-115. doi: 10.1016/j.jep.2010. 04.025

Kaur, S., Modi, N. H., Panda, D., and Roy, N. (2010). Probing the binding site of curcumin in Escherichia coli and Bacillus subtilis FtsZ-a structural insight to unveil antibacterial activity of curcumin. Eur. J. Med. Chem. 45, 4209-4214. doi: 10.1016/j.ejmech.2010.06.015

Khorrami, S., Zarrabi, A., Khaleghi, M., Danaei, M., and Mozafari, M. R. (2018). Selective cytotoxicity of green synthesized silver nanoparticles against the MCF7 tumor cell line and their enhanced antioxidant and antimicrobial properties. Int. J. Nanomed. 13, 8013-8024. doi: 10.2147/IJN.S189295

Krausz, A. E., Adler, B. L., Cabral, V., Navati, M., Doerner, J., Charafeddine, R. A., et al. (2015). Curcumin-encapsulated nanoparticles as innovative antimicrobial and wound healing agent. Nanomedicine 11, 195-206. doi: 10.1016/j.nano.2014. 09.004

Lakshmi, S., Padmaja, G., and Remani, P. (2011). Antitumour Effects of Isocurcumenol Isolated from Curcuma zedoaria Rhizomes on Human and Murine Cancer Cells. Int. J. Med. Chem. 2011:253962. doi: 10.1155/2011/ 253962

Lee, J. Y., Garcia, C. V., Shin, G. H., and Kim, J. T. (2019). Antibacterial and antioxidant properties of hydroxypropyl methylcellulose-based active composite films incorporating oregano essential oil nanoemulsions. LWT 106, 164-171. doi: 10.1016/j.lwt.2019.02.061

Lee, W.-H., Bebawy, M., Loo, C.-Y., Luk, F., Mason, R. S., and Rohanizadeh, R. (2015). Fabrication of Curcumin Micellar Nanoparticles with Enhanced AntiCancer Activity. J. Biomed. Nanotechnol. 11, 1093-1105. doi: 10.1166/jbn.2015. 2041

Levy, S. B., and Marshall, B. (2004). Antibacterial resistance, worldwide: causes, challenges and responses. Nat. Med. 10, 122-129. doi: 10.1038/nm1145

Leyva-Lopez, N., Gutierrez-Grijalva, E., Vazquez-Olivo, G., and Heredia, B. (2017). Essential oils of oregano: biological activity beyond their antimicrobial properties. Molecules 22:989. doi: 10.3390/molecules22060989

Li, B., Li, X., Lin, H., and Zhou, Y. (2018). Curcumin as a Promising Antibacterial Agent: Effects on Metabolism and Biofilm Formation in S. mutans. Biomed. Res. Int. 2018:4508709. doi: 10.1155/2018/4508709

Li, J., Huang, Q., Zheng, X., Ge, Z., Lin, K., Zhang, D., et al. (2020). Investigation of the lactic acid bacteria in Kazak cheese and their contributions to cheese formation. Front. Microbiol. 11:228. doi: 10.3389/fmicb.2020.00228

Loo, C.-Y., Rohanizadeh, R., Young, P. M., Traini, D., Cavaliere, R., Whitchurch, C. B., et al. (2016). Combination of Silver Nanoparticles and Curcumin Nanoparticles for Enhanced Anti-biofilm Activities. J. Agric. Food Chem. 64, 2513-2522. doi: 10.1021/acs.jafc.5b0 4559

Loo, C.-Y., Young, P. M., Cavaliere, R., Whitchurch, C. B., Lee, W.-H., and Rohanizadeh, R. (2014). Silver nanoparticles enhance Pseudomonas aeruginosa PAO1 biofilm detachment. Drug Dev. Ind. Pharm. 40, 719-729. doi: 10.3109/ 03639045.2013 .780182

Lopez-Romero, J. C., González-Ríos, H., Borges, A., and Simões, M. (2015). Antibacterial Effects and Mode of Action of Selected Essential Oils Components against Escherichia coli and Staphylococcus aureus. Evid. Based Compl. Alternat. Med. 2015:e795435. doi: 10.1155/2015/79 5435

Lou, Z., Letsididi, K. S., Yu, F., Pei, Z., Wang, H., and Letsididi, R. (2019). Inhibitive effect of eugenol and its nanoemulsion on quorum sensing-mediated virulence factors and biofilm formation by Pseudomonas aeruginosa. J. Food Prot. 82, 379-389. doi: 10.4315/0362-028X.JFP-18- 196

Luis, A. I. S., Campos, E. V. R., Oliveira, J. L., Guilger-Casagrande, M., Lima, R., Castanha, R. F., et al. (2020). Zein nanoparticles impregnated with eugenol and garlic essential oils for treating fish pathogens. ACS Omega 16, 15557-15566. doi: 10.1021/acsomega.0c01716 
Luthra, P. M., Singh, R., and Chandra, R. (2001). Therapeutic uses of Curcuma longa (turmeric). Indian J. Clin. Biochem. 16, 153-160. doi: 10.1007/ BF02864854

Ma, H., Wang, Q., Qian, D., Gong, L., and Zhang, W. (2009). The utilization of acid-tolerant on ethanol production from kitchen garbage. Renew. Energy 34, 1466-1470. doi: 10.1016/j.renene.2008.10.020

Maghimaa, M., and Alharbi, S. A. (2020). Green synthesis of silver nanoparticles from Curcuma longa L. and coating on the cotton fabrics for antimicrobial applications and wound healing activity. J. Photochem. Photobiol. 204:111806. doi: 10.1016/j.jphotobiol.2020.111806

Mali, S. C., Dhaka, A., Githala, C. K., and Trivedi, R. (2020). Green synthesis of copper nanoparticles using Celastrus paniculatus Willd. leaf extract and their photocatalytic and antifungal properties. Biotechnol. Rep. 27:e00518. doi: 10. 1016/j.btre.2020.e00518

Malik, E. M., and Müller, C. E. (2016). Anthraquinones As Pharmacological Tools and Drugs. Med. Res. Rev. 36, 705-748. doi: 10.1002/med.2 1391

Marchese, A., Barbieri, R., Coppo, E., Orhan, I. E., Daglia, M., Nabavi, S. F., et al. (2017). Antimicrobial activity of eugenol and essential oils containing eugenol: a mechanistic viewpoint. Crit. Rev. Microbiol. 43, 668-689. doi: 10. 1080/1040841X.2017.1295225

Meretoudi, A., Banti, C. N., Raptis, P. K., Papachristodoulou, C., Kourkoumelis, N., Ikiades, A. A., et al. (2021). Silver nanoparticles from oregano leaves' extracts as antimicrobial components for non-infected hydrogel contact lenses. Int. J. Mol. Sci. 22:3539. doi: 10.3390/ijms22073539

Milkman, R. (1990). Gene transfer in the environment. Stuart B. Levy and Robert V. Miller. McGraw-Hill, New York, 1989. x, 434 pp., illus. \$54.95. Environmental biotechnology. Science 247, 350-351. doi: 10.1126/science.247. 4940.350

Mir, M., Permana, A. D., Ahmed, N., Khan, G. M., Rehman, A. U., and Donnelly, R. F. (2020). Enhancement in site-specific delivery of carvacrol for potential treatment of infected wounds using infection responsive nanoparticles loaded into dissolving microneedles: A proof of concept study. Eur. J. Pharm. Biopharm. 147, 57-68. doi: 10.1016/j.ejpb.2019.1 2.008

Mith, H., Clinquart, A., Zhiri, A., Daube, G., and Delcenserie, V. (2015). The impact of oregano (Origanum heracleoticum) essential oil and carvacrol on virulence gene transcription by Escherichia coli O157:H7. FEMS Microbiol. Lett. 362, 1-7. doi: 10.1093/femsle/fnu021

Moraes-Lovison, M., Marostegan, L. F. P., Peres, M. S., Menezes, I. F., Ghiraldi, M., Rodrigues, R. A. F., et al. (2017). Nanoemulsions encapsulating oregano essential oil: Production, stability, antibacterial activity and incorporation in chicken pâté. LWT 2017, 233-240. doi: 10.1016/j.lwt.2016.1 1.061

Mukherjee, R., Dutta, D., Patra, M., Chatterjee, B., and Basu, T. (2019). Nanonized tetracycline cures deadly diarrheal disease "shigellosis" in mice, caused by multidrug-resistant Shigella flexneri 2a bacterial infection. Nanomedicine $18, \quad 402-413$. doi: 10.1016/j.nano.2018.1 1.004

Mwangi, J., Yin, Y., Wang, G., Yang, M., Li, Y., Zhang, Z., et al. (2019). The antimicrobial peptide ZY4 combats multidrug-resistant Pseudomonas aeruginosa and Acinetobacter baumannii infection. Proc. Natl. Acad. Sci. U.S.A. 116, 265516-265522. doi: 10.1073/pnas.1909585117

Nayak, S., Goveas, L. C., and Rao, V. (2017). "Biosynthesis of silver nanoparticles using turmeric extract and evaluation of its anti-bacterial activity and catalytic reduction of methylene blue," in Materials, Energy and Environment Engineering, eds B. R. Mohan, G. Srinikethan, and B. Meikap (Singapore: Springer).

Ozkan, O. E., Guney, K., Gur, M., Pattabaglou, E. S., Babat, E., and Khalifa, M. M. (2017). Essential oil of oregano and savory; chemical composition and antimicrobial activity. Indian J. Pharm. Educ. Res. 51, 205-208. doi: 10.5530/ ijper.51.3s.13

Pathania, R., Khan, H., Kaushik, R., and Khan, M. A. (2018). Essential oil nanoemulsions and their antimicrobial and food applications. Curr. Res. Nutr. Food Sci. 6, 626-643. doi: 10.12944/CRNFSJ.6.3.05

Pattanayak, P., Behera, P., Das, D., and Panda, S. K. (2010). Ocimum sanctum Linn. A reservoir plant for therapeutic applications: an overview. Pharmacogn. Rev. 4, 95-105. doi: 10.4103/0973-7847.65323
Pena, R. T., Blasco, L., Ambroa, A., González-Pedrajo, B., Fernández-García, L., López, M., et al. (2019). Relationship between quorum sensing and secretion systems. Front Microbiol. 10:1100. doi: 10.3389/fmicb.2019.01100

Prakash, P., and Gupta, N. (2005). Therapeutic uses of Ocimum sanctum Linn (Tulsi) with a note on eugenol and its pharmacological actions: a short review. Indian J. Physiol. Pharmacol. 49, 125-131.

Prentice, M. B., and Rahalison, L. (2007). Plague. Lancet 369, 1196-1207. doi: 10.1016/S0140-6736(07)60566-2

Quatrin, P. M., Verdi, C. M., de Souza, M. E., de Godoi, S. N., Klein, B., Gundel, A., et al. (2017). Antimicrobial and antibiofilm activities of nanoemulsions containing Eucalyptus globulus oil against Pseudomonas aeruginosa and Candida spp. Microb. Pathog. 112, 230-242. doi: 10.1016/j.micpath.2017.0 9.062

Rafiee, Z., Nejatian, M., Daeihamed, M., and Jafari, S. M. (2019). Application of curcumin-loaded nanocarriers for food, drug and cosmetic purposes. Trends Food Sci. Technol. 88, 445-458. doi: 10.1016/j.tifs.2019.04.017

Raaijmakers, J. M., Vlami, M., and Souza, J. T. (2002). Antibiotic production by bacterial biocontrol agents. Antonie Van Leeuwenhoek 81, 537-547. doi: 10.1023/a:1020501420831

Ramkumar, V. S., Pugazhendhi, A., Gopalakrishnan, K., Sivagurunathan, P., Saratale, G. D., Dung, T. N. B., et al. (2017). Biofabrication and characterization of silver nanoparticles using aqueous extract of seaweed Enteromorpha compressa and its biomedical properties. Biotechnol. Rep. 14, 1-7. doi: 10.1016/ j.btre.2017.02.001

Ramteke, C., Chakrabarti, T., Sarengi, B. K., and Pandey, R. A. (2013). Synthesis of silver nanoparticles from the aqueous extract of leaves of Ocimum sanctum for enhanced antibacterial activity. J. Chem. 2013:278925. doi: 10.1155/2013/ 278925

Rao, S., Xu, G., Zeng, H., Zheng, X., Hu, Q., Wang, Q., et al. (2020). Physicochemical and antibacterial properties of fabricated ovalbumincarvacrol gel nanoparticles. Food Funct. 11, 5133-5141. doi: 10.1039/ D0FO00755B

Rathinam, P., Vijay Kumar, H. S., and Viswanathan, P. (2017). Eugenol exhibits anti-virulence properties by competitively binding to quorum sensing receptors. Biofouling 33, 624-639. doi: 10.1080/08927014.2017.1350655

Rodenak-Kladniew, B., Scioli Montoto, S., Sbaraglini, M. L., Di Ianni, M., Ruiz, M. E., Talevi, A., et al. (2019). Hybrid Ofloxacin/eugenol co-loaded solid lipid nanoparticles with enhanced and targetable antimicrobial properties. Int. J. Pharm. 569:118575. doi: 10.1016/j.ijpharm.2019.118575

Roy, S. (2011). Everything About Aloe vera. TOI.

Saidin, S., Jumat, M. A., Amin, M. A. A. N., and Saleh Al-Hammadi, A. (2021). Organic and inorganic antibacterial approaches in combating bacterial infection for biomedical application. Mater. Sci. Eng. C 118:111382. doi: 10. 1016/j.msec.2020.111382

Saleem, S., Ahmed, B., Khan, M. S., Al-Shaeri, M., and Musarrat, J. (2017). Inhibition of growth and biofilm formation of clinical bacterial isolates by $\mathrm{NiO}$ nanoparticles synthesized from Eucalyptus globulus plants. Microb. Pathog. 111, 375-387. doi: 10.1016/j.micpath.2017.09.019

Sarmukaddam, S., Chopra, A., and Tillu, G. (2010). Efficacy and safety of Ayurvedic medicines: recommending equivalence trial design and proposing safety index. Int. J. Ayurveda Res. 1, 175-180. doi: 10.4103/0974-7788.7 2491

Schneiders, T., Amyes, S. G. B., and Levy, S. B. (2003). Role of AcrR and RamA in fluoroquinolone resistance in clinical Klebsiella pneumoniae isolates from Singapore. Antimicrob. Agents Chemother. 47, 2831-2837. doi: 10.1128/AAC. 47.9.2831-2837.2003

Sdrolia, E., and Zarotiadis, G. (2018). A comprehensive review for green product term: from definition to evaluation. J. Econ. Sur. 33, 150-178. doi: 10.1111/joes. 12268

Shanan, Z. J., Hadi, S. M., and Shansool, S. K. (2018). Structural analysis of chemical and green synthesis of $\mathrm{CuO}$ nanoparticles and their effect on biofilm formation. Baghdad Sci. J. 15, 211-216. doi: 10.21123/bsj.2018.15.2.0211

Sharifi-Rad, J., Rayees, Y. E., Rizk, A. A., Sadaka, C., Zgheib, R., Zam, W., et al. (2020). Turmeric and its major compound curcumin on health: bioactive effects and safety profiles for food, pharmaceutical, biotechnological and medicinal applications. Front. Pharmacol. 11:01021. doi: 10.3389/fphar.2020.01021

Sharifi-Rad, M., Varoni, E. M., Iriti, M., Martorell, M., Setzer, W. N., Del Mar Contreras, M., et al. (2018). Carvacrol and human health: a 
comprehensive review. Phytother. Res. 32, 1675-1687. doi: 10.1002/ptr. 6103

Singh, R., and Singh, P. (2014). Microorganism as a tool of bioremediation technology for cleaning environment: a review. Proc. Int. Acad. Ecol. Environ. Sci. 4, 1-6.

Singh, V., Amdekar, S., and Verma, O. (2010). Ocimum sanctum (tulsi): biopharmacological activities. Webmed Cent. Pharmacol. 1:WMC001046. doi: 10. 9754/journal.wmc.2010.001046

Sivasakthi, S., Usharani, G., and Saranraj, P. (2014). Biocontrol potentiality of plant growth promoting bacteria (pgpr) - Pseudomonas fluorescens and Bacillus subtills: a review. Afr. J. Agric. Res. 9, 1265-1277. doi: 10.5897/AJAR2013.7914

Soenen, S. J., Rivera-Gil, P., Montenegro, J.-M., Parak, W. J., De Smedt, S. C., and Braeckmans, K. (2011). Cellular toxicity of inorganic nanoparticles: Common aspects and guidelines for improved nanotoxicity evaluation. Nano Today 6, 446-465. doi: 10.1016/j.nantod.2011.0 8.001

Stephens, D. S., Greenwood, B., and Brandtzaeg, P. (2007). Epidemic meningitis, meningococcaemia, and Neisseria meningitidis. Lancet 369, 2196-2210. doi: 10.1016/S0140-6736(07)61016-2

Sugumar, S., Ghosh, V., Nirmala, M. J., Mukherjee, A., and Chandrasekaran, N. (2014). Ultrasonic emulsification of eucalyptus oil nanoemulsion: antibacterial activity against Staphylococcus aureus and wound healing activity in Wistar rats. Ultrason. Sonochem. 21, 1044-1049. doi: 10.1016/j.ultsonch.2013.1 0.021

Sugumar, S., Mukherjee, A., and Chandrasekaran, N. (2015). Eucalyptus oil nanoemulsionimpregnated chitosan film: antibacterial effects against a clinical pathogen, Staphylococcus aureus, in vitro. Int. J. Nanomed. 10, 67-75. doi: 10.2147/IJN.S79982

Sulaiman, G. M., Mohammed, W. H., Marzoog, T. R., Al-Amiery, A. A. A., Kadhum, A. A. H., and Mohamad, A. B. (2013). Green synthesis, antimicrobial and cytotoxic effects of silver nanoparticles using Eucalyptus chapmaniana leaves extract. Asian Pac. J. Trop. Biomed. 3, 58-63. doi: 10.1016/S22211691(13)60024-6

Sun, Y., Du, L., Liu, Y., Li, X., Li, M., Jin, Y., et al. (2014). Transdermal delivery of the in situ hydrogels of curcumin and its inclusion complexes of hydroxypropyl$\beta$-cyclodextrin for melanoma treatment. Int. J. Pharm. 469, 31-39. doi: 10.1016/ j.ijpharm.2014.04.039

Surjushe, A., Vasani, R., and Saple, D. G. (2008). Aloe vera: a short review. Indian J. Dermatol. 53, 163-166. doi: 10.4103/0019-5154.4 4785

Ticlla, M. R., Hella, J., Hiza, H., Sasamalo, M., Mhimbira, F., Rutaihwa, L. K., et al. (2021). The sputum microbiome in pulmonary tuberculosis and its association with disease manifestations: a cross-sectional study. Front. Microbiol. 12:633396. doi: 10.3389/fmicb.2021.633396

Tsuji, M., Suzuki, K., Kinoshita, K., and Fagarasan, S. (2008). Dynamic interactions between bacteria and immune cells leading to intestinal IgA synthesis. Semin. Immunol. 20, 59-66. doi: 10.1016/j.smim.2007.12.003

Tyagi, P., Singh, M., Kumari, H., Kumari, A., and Mukhopadhyay, K. (2015). Bactericidal activity of curcumin I is associated with damaging of bacterial membrane. PLoS One 10:e0121313. doi: 10.1371/journal.pone.0121313

Varghese, B., Krishna, S., and Athira, T. (2020). Biochemical synthesis of copper nanoparticles using Zingiber officinalis and Curcuma longa: characterization and antibacterial activity study. Mater. Today Proc. 25, 302-306. doi: 10.1016/j. matpr.2020.01.476

Velez, E., Campillo, G., Morales, G., Hincaple, C., Osorio, J., and Arnache, O. (2018). Silver nanoparticles obtained by aqueous or ethanolic Aloe vera extracts: an assessment of the antibacterial activity and mercury removal capability. J. Nanomater. 2018:7215210. doi: 10.1155/2018/7215210

Vijay Kumar, P. P. N., Shameen, U., Kollu, P., Kalyani, R., and Pammi, S. (2015). Green synthesis of copper oxide nanoparticles using Aloe vera leaf extract and its antibacterial activity against fish bacterial pathogens. BioNanoScience 5 , 135-139.

Wijesundara, N. M., Lee, S. F., Cheng, Z., Davidson, R., and Rupasinghe, H. P. V. (2021). Carvacrol exhibits rapid bactericidal activity against Streptococcus pyogenes through cell membrane damage. Sci. Rep. 11:1487. doi: 10.1038/ s41598-020-79713-0

Wintachai, P., Paosen, S., Yupanqui, C. T., and Voravuthikunchai, S. P. (2019). Silver nanoparticles synthesized with Eucalyptus critriodora ethanol leaf extract stimulate antibacterial activity against clinically multidrug-resistant
Acinetobacter baumannii isolated from pneumonia patients. Microb. Pathog. 126, 245-257. doi: 10.1016/j.micpath.2018.11.018

Workowski, K. M., Bolan, A. G., and Centers for Disease Control and Prevention (2015). Sexually transmitted diseases treatment guidelines, 2015. MMWR Recomm. Rep. 5, 1-137.

Xia, T., Kovochich, M., Liong, M., Mädler, L., Gilbert, B., Shi, H., et al. (2008). Comparison of the mechanism of toxicity of zinc oxide and cerium oxide nanoparticles based on dissolution and oxidative stress properties. ACS Nano 28, 2121-2134. doi: $10.1021 / \mathrm{nn} 800511 \mathrm{k}$

Xu, J., Zhou, F., Ji, B. P., Pei, R. S., and Xu, N. (2008). The antibacterial mechanism of carvacrol and thymol against Escherichia coli. Lett. Appl. Microbiol. 47, 174-179. doi: 10.1111/j.1472-765X.2008.02407.x

Yadav, J. P., and Kumar, S. (2016). Characterization and Antibacterial Activity of Synthesized Silver and Iron Nanoparticles using Aloe vera. J. Nanomed. Nanotechnol. 7:1000384. doi: 10.4172/2157-7439.1000384

Yamano, Y. (2019). In Vitro Activity of Cefiderocol Against a Broad Range of Clinically Important Gram-negative Bacteria. Clin. Infect Dis. 69, S544-S551. doi: $10.1093 / \mathrm{cid} / \mathrm{ciz} 827$

Yang, Q.-Q., Farha, A. K., Kim, G., Gul, K., Gan, R.-Y., and Corke, H. (2020). Antimicrobial and anticancer applications and related mechanisms of curcumin-mediated photodynamic treatments. Trends Food Sci. Technol. 97, 341-354. doi: 10.1016/j.tifs.2020.01.023

Yeung, A. W. K., Horbańczuk, M., Tzvetkov, N. T., Mocan, A., Carradori, S., Maggi, F., et al. (2019). Curcumin: Total-Scale Analysis of the Scientific Literature. Molecules 24:E1393. doi: 10.3390/molecules 24071393

Yin, I. X., Zhang, J., Zhao, I. S., Mei, M. L., Li, Q., and Chu, C. H. (2020). The Antibacterial Mechanism of Silver Nanoparticles and Its Application in Dentistry. Int. J. Nanomed. 15, 2555-2562. doi: 10.2147/IJN.S246764

Youngsukkasem, S., Rakshit, S. K., and Taherzadeh, M. J. (2012). Biogas production by encapsulated methane producing bacteria. BioRes 7, 56-65. doi: 10.3390/ membranes 4030596

Yun, D. G., and Lee, D. G. (2016). Antibacterial activity of curcumin via apoptosislike response in Escherichia coli. Appl. Microbiol. Biotechnol. 100, 5505-5514. doi: 10.1007/s00253-016-7415-x

Zagora-Dziok, M., Furman-Toczek, D., Dudra-Jastrzebska, M., Zygo, K., Stanislaweek, A., and Kapka-Skrzypczak, L. (2017). Evaluation of clinical effectiveness of Aloe vera - a review. J. Pre Clin. Clin. Res. 11, 86-93. doi: $10.26444 / \mathrm{jpccr} / 74577$

Zamare, M. S. D., Vutukuru, S. S., and Babu, R. (2016). Biosynthesis of nanoparticles from agro-waste: a sustainable approach. Int. J. Eng. Appl. Sci. Technol. 1, 85-92. doi: 10.1007/s11356-020-11435-2

Zhang, D. X., Li, Y., Yang, X. Q., Su, H. Y., Wang, Q., Zhang, Z. H., et al. (2020). In vitro antibiotic susceptibility, virulence genes distribution and biofilm production of Staphylococcus aureus isolates from bovine mastitis in the liaoning province of China. Infect. Drug Resist. 13, 1365-1375. doi: 10.2147/ IDR.S247765

Zhang, M., Zhuang, B., Du, G., Han, G., and Jin, Y. (2019). Curcumin solid dispersion-loaded in situ hydrogels for local treatment of injured vaginal bacterial infection and improvement of vaginal wound healing. J. Pharm. Pharmacol. 71, 1044-1054. doi: 10.1111/jphp.13088

Zhang, Y. J., Li, S., Gan, R. Y., Zhou, T., Xu, D. P., and Li, H. B. (2015). Impacts of gut bacteria on human health and diseases. Int. J. Mol. Sci. 16, 7493-7519.

Conflict of Interest: The authors declare that the research was conducted in the absence of any commercial or financial relationships that could be construed as a potential conflict of interest.

Publisher's Note: All claims expressed in this article are solely those of the authors and do not necessarily represent those of their affiliated organizations, or those of the publisher, the editors and the reviewers. Any product that may be evaluated in this article, or claim that may be made by its manufacturer, is not guaranteed or endorsed by the publisher.

Copyright $(2022$ Ghosh, Nandi and Basu. This is an open-access article distributed under the terms of the Creative Commons Attribution License (CC BY). The use, distribution or reproduction in other forums is permitted, provided the original author(s) and the copyright owner(s) are credited and that the original publication in this journal is cited, in accordance with accepted academic practice. No use, distribution or reproduction is permitted which does not comply with these terms. 